\title{
Sarcoptic mange: An emerging panzootic in wildlife
}

\author{
Luis E. Escobar ${ }^{1}$ (D) | Scott Carver ${ }^{2}$ (D) | Paul C. Cross ${ }^{3}$ | Luca Rossi ${ }^{4}$ | \\ Emily S. Almberg $^{5}$ | Michael J. Yabsley ${ }^{6,7}$ (D) | Kevin D. Niedringhaus ${ }^{6}$ | \\ Peach Van Wick $^{8}$ | Ernesto Dominguez-Villegas ${ }^{8}$ | Francis Gakuya ${ }^{9}$ | \\ Yue Xie $^{10}$ | Samer Angelone ${ }^{11}$ | Christian Gortázar ${ }^{12}$ (D) | \\ Francisca Astorga ${ }^{13}$
}

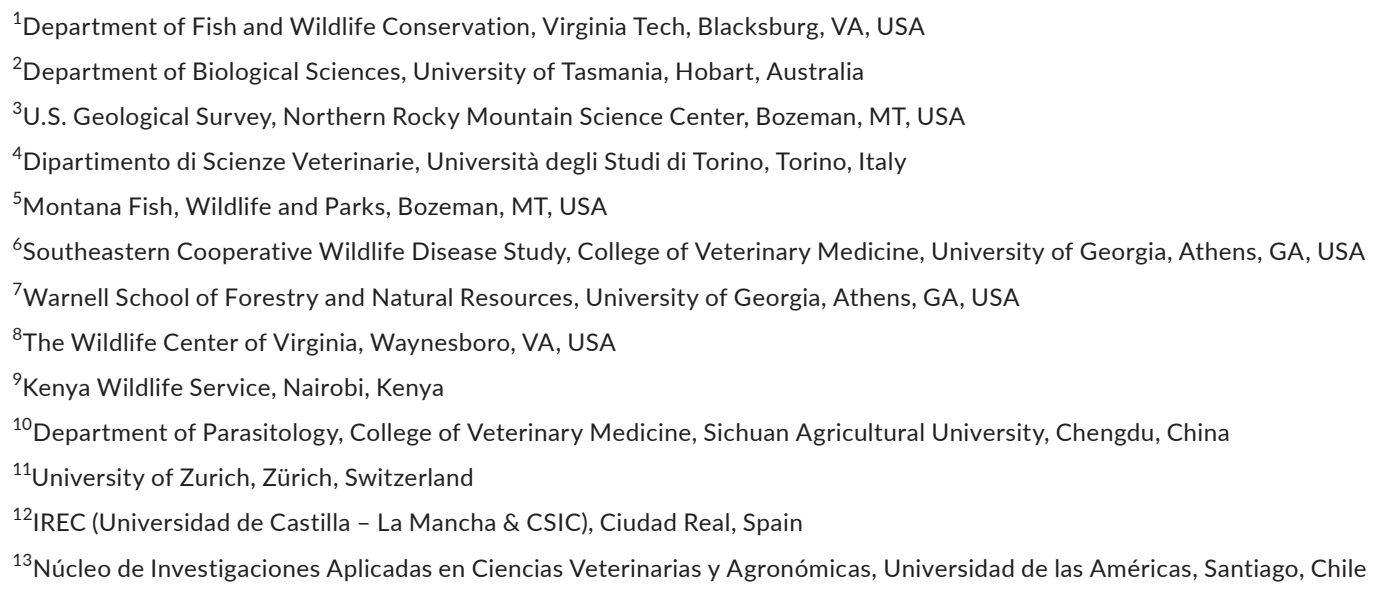

${ }^{1}$ Department of Fish and Wildlife Conservation, Virginia Tech, Blacksburg, VA, USA

${ }^{2}$ Department of Biological Sciences, University of Tasmania, Hobart, Australia

${ }^{3}$ U.S. Geological Survey, Northern Rocky Mountain Science Center, Bozeman, MT, USA

${ }^{4}$ Dipartimento di Scienze Veterinarie, Università degli Studi di Torino, Torino, Italy

${ }^{5}$ Montana Fish, Wildlife and Parks, Bozeman, MT, USA

${ }^{6}$ Southeastern Cooperative Wildlife Disease Study, College of Veterinary Medicine, University of Georgia, Athens, GA, USA

${ }^{7}$ Warnell School of Forestry and Natural Resources, University of Georgia, Athens, GA, USA

${ }^{8}$ The Wildlife Center of Virginia, Waynesboro, VA, USA

${ }^{9}$ Kenya Wildlife Service, Nairobi, Kenya

${ }^{10}$ Department of Parasitology, College of Veterinary Medicine, Sichuan Agricultural University, Chengdu, China

${ }^{11}$ University of Zurich, Zürich, Switzerland

${ }^{12}$ IREC (Universidad de Castilla - La Mancha \& CSIC), Ciudad Real, Spain

${ }^{13}$ Núcleo de Investigaciones Aplicadas en Ciencias Veterinarias y Agronómicas, Universidad de las Américas, Santiago, Chile

\section{Correspondence}

Luis E. Escobar, Department of Fish and Wildlife Conservation, Virginia Tech, 310 West Campus Drive, Rm 101, Blacksburg, VA, USA.

Email: escobar1@vt.edu

Funding information

The Australian Research Council Linkage Project (LP180101251) provided funding support to Scott Carver. Additional support was given by the Seed Grants of the Global Change Center and the Center for Emerging, Zoonotic, and Arthropod-borne Pathogens of Virginia Tech.

\begin{abstract}
Sarcoptic mange, a skin infestation caused by the mite Sarcoptes scabiei, is an emerging disease for some species of wildlife, potentially jeopardizing their welfare and conservation. Sarcoptes scabiei has a near-global distribution facilitated by its forms of transmission and use of a large diversity of host species (many of those with broad geographic distribution). In this review, we synthesize the current knowledge concerning the geographic and host taxonomic distribution of mange in wildlife, the epidemiological connections between species, and the potential threat of sarcoptic mange for wildlife conservation. Recent sarcoptic mange outbreaks in wildlife appear to demonstrate ongoing geographic spread, increase in the number of hosts and increased virulence. Sarcoptic mange has been reported in at least 12 orders, 39 families and 148 species of domestic and wild mammals, making it one of the most generalist ectoparasites of mammals. Taxonomically, the orders with most species found infested so far include Perissodactyla ( $67 \%$ species from the entire order), Artiodactyla (47\%), and Diprotodontia (67\% from this order). This suggests that new species from these mammal orders are likely to suffer cross-species transmission and be reported positive to sarcoptic mange as surveillance improves. We propose a new agenda for the study of sarcoptic mange in wildlife, including the study of the global phylogeography of S. scabiei, linkages between ecological host traits and sarcoptic
\end{abstract}


mange susceptibility, immunology of individuals and species, development of control strategies in wildlife outbreaks and the effects of global environmental change in the sarcoptic mange system. The ongoing transmission globally and sustained spread among areas and wildlife species make sarcoptic mange an emerging panzootic in wildlife. A better understanding of sarcoptic mange could illuminate the aspects of ecological and evolutionary drivers in cross-species transmission for many emerging diseases.

KEYWORDS

panzootic, Sarcoptes, spillover, wildlife conservation, wildlife disease

\section{1 | INTRODUCTION}

There are more than 55,000 known species of mites, with at least 50 of them causing different types of mange diseases (Kraabøl et al., 2015; OIE, 2016). Sarcoptes scabiei, the causative agent of sarcoptic mange, is arguably the most important mite species in terms of number of domestic and wildlife species affected (Gortázar et al., 2007). Sarcoptic mange (also termed 'scabies' in humans) is a highly contagious skin disease of mammals that can form acute or chronic infections depending on factors such as host immunity and mite lineage (Bornstein et al., 2001). Nevertheless, many aspects driving the severity of disease among species are yet to be fully understood (Astorga, Carver, et al., 2018; Kumar et al., 2018). Previous studies have suggested that sarcoptic mange could represent a threat for wildlife, considering its potential severity, morbidity, the wide range of host species affected and its global distribution (Gortázar et al., 2007; Tompkins et al., 2015). Even though $S$. scabiei is categorized as a multi-host parasite, there is still debate concerning host specificity (Arlian et al., 1988; Fazal et al., 2016; Matsuyama et al., 2019), which could be an important baseline to predict its virulence in novel hosts and explore potential cross-species transmission dynamics. Our understanding of the panzootic (i.e. a pandemic in animals) nature of sarcoptic mange, including epidemiology, host specificity and spillover potential in wildlife, is limited (Arlian et al., 2016; Astorga, Carver, et al., 2018). The goal of this review is to synthesize our current understanding of $S$. scabiei in wildlife at a global scale, particularly concerning its host range, crossspecies transmission events (i.e. parasite spillover) and potential threat for wildlife conservation.

\section{LITERATURE SEARCH}

We developed a literature search to detect all susceptible species and the first record of each one of them, collect data concerning crossspecies transmission events and review relevant aspects of sarcoptic mange in wildlife. As a first step for collecting literature, we used the terms 'Sarcoptes AND wild' and 'Sarcoptes AND transmission' for all available publications in Scopus and in Google Scholar, limiting results from 2016 to 2019. Then, we manually listed in two separated spreadsheets all studies that reported cross-species transmission, and the oldest study that reported susceptible hosts, excluding duplicate reports. We defined a susceptible host as any animal species in which S. scabiei was reported to be infested by the parasite. In addition to the studies published within our filter (2016-2019), we included reports beyond this period by (i) searching for the first available report of each of the host species described and (ii) reviewing the references cited in the manuscripts collected in the first search. We merged the list of all reported host susceptible species and retain the oldest study registering the year, the free-ranging or in-captivity (e.g. zoo, laboratory) status, the geographic location and the source of data (i.e. scientific literature, book, grey literature). Host species were characterized according to their updated taxonomy using the Integrated Taxonomic Information System (ITIS, 2020), their conservation status (IUCN, 2019), their domestic or wild status, and their solitary or gregarious behaviour.

The literature search included the identification and registration of all available studies describing transmission of sarcoptic mange between different host species (i.e. cross-species transmission), accounting for the type of transmission (i.e. experimental or observational; detailed data of transmission links are available in Table S1 and Material S1). We included also those studies that suggest no transmission (e.g. based on distant genetic clustering of the S. scabiei populations), or those experimental studies that failed in generating cross-species transmission. These data were used to identify transmission linkages among host species to reconstruct host-parasite interactions. Finally, we developed a scoping study concerning current knowledge of sarcoptic mange in wildlife and assessed the negative impacts of $S$. scabiei infestation at the individual, population, community and species levels, and potential effects for biological conservation. Findings of this review are expected to help identify gaps of knowledge in sarcoptic mange research and to propose future research directions.

\section{3 | HOST DIVERSITY, GEOGRAPHICAL DISTRIBUTION AND SPATIAL SPREAD}

Our sarcoptic mange review revealed that hosts include 12 orders, 39 families and 148 species of domestic and wild mammals, with a 
near-global distribution (Figures 1 and 2, Material S2). This list positions sarcoptic mange among the terrestrial ectoparasites with the widest host range (Currier et al., 2012; Pence \& Ueckermann, 2002). The search of the first scientific records of infestation among animal hosts revealed that $S$. scabiei was first reported in sheep (Ovis aries) in 1809 (Walz, 1809), that wolf (Canis lupus) was the first wild host reported in captivity (Bourguignon, 1851), and that the first free-ranging wildlife host was the red fox (Vulpes vulpes; Fürstenberg, 1861). Our review complements and updates a previous list of sarcoptic mange hosts published by Bornstein et al. (2001). We include new species described in the last two decades confirming the large host range of $S$. scabiei and the consistent identification of new hosts (Figure 3), with an average of nine new hosts described by decade since 1970 . All of the recently reported species are freeranging wildlife.

In addition, recent studies describe new locations of mange outbreaks. For example, S. scabiei in red foxes is endemic in specific areas in Europe, but recent outbreaks are increasingly being reported in new locations, depicting spatial spread (Soulsbury et al., 2007). Similar geographical expansions have been described in wildlife in North America (Niedringhaus et al., 2019), Asia (Makouloutou et al., 2015) and South America (Montecino-Latorre et al., 2020). The spatial spread of sarcoptic mange during introduction into naïve host populations ranges from speeds of $0.7 \mathrm{~km} /$ year (Martin et al., 2018) to $20 \mathrm{~km}$ /year (Fuchs et al., 2000). Sarcoptic mange spread generally mirrors the distribution, population structure and dispersal behaviour of host species infected (Lindström \& Mörner, 1985; Pence \& Windberg, 1994; Rossi et al., 2007), consistent with other wildlife diseases (Astorga, Escobar, et al., 2018). Possible explanations of these geographical expansions include transmission to populations lacking immune resistance (Peltier et al., 2017; Pence \& Windberg, 1994; Soulsbury et al., 2007). Host and geographical areas affected by S. scabiei can be biased towards species and regions well monitored (e.g. of conservation concern), improved detection and reporting of wildlife diseases, more frequent contact between humans and wildlife, and other elements already described for wildlife diseases (Ryser-Degiorgis, 2013; Woods et al., 2019). Spatial spread and novel severe outbreaks of sarcoptic mange have also been associated with S. scabiei lineages that may present higher virulence (Makouloutou et al., 2015; Pence \& Windberg, 1994). Therefore, S. scabiei may be described as a widespread ectoparasite, with a consistent increase in geographic distribution and number of host species infested.

\section{4 | HOST SPECIFICITY}

Some authors have considered S. scabiei as a single species, with lineages associated with different host species-for example $S$. scabiei var. hominis in humans, var. canis in dogs (Canis lupus familiaris) and var. vulpes in red foxes (Arlian et al., 1996). Nevertheless, the accuracy of S. scabiei lineages to denote host specificity is unclear (Fraser et al., 2016). Sarcoptes scabiei lineages have been historically named based on the host where they were collected, with contradictory evidence concerning features to categorize $S$. scabiei groups. In fact, S. scabiei variants have shown little to nil morphological differences (Fain, 1968). According to Arlian et al. (1988), there is biological evidence supporting physiologically differences among S. scabiei lineages expressed as differences in transmission success (Arlian et al., 1988). For example, experimental exposures of S. scabiei from humans (i.e. var. hominis) and pigs (var. suis) failed

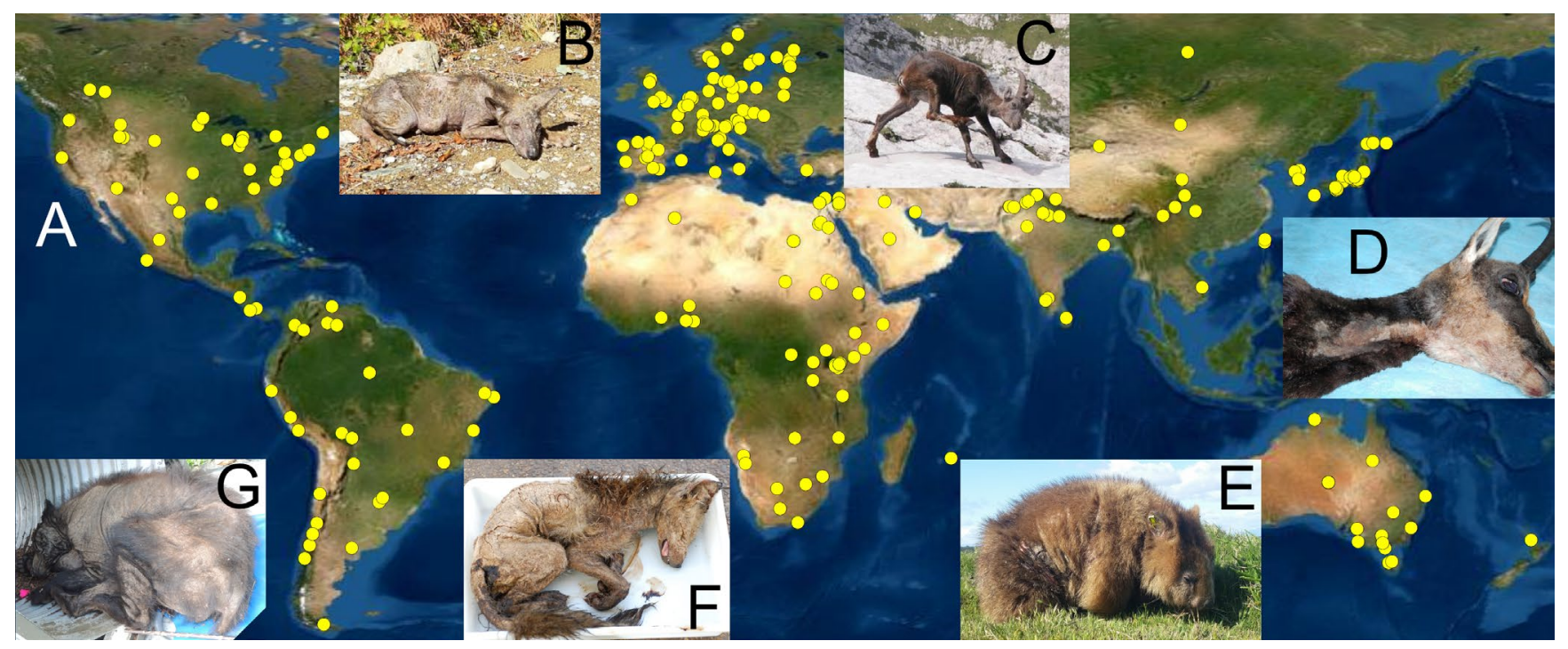

FIGURE 1 Geographic distribution of sarcoptic mange in wildlife. Sarcoptic mange has been reported in at least 148 species on six continents, with evidence of ongoing host and spatial expansion. (a) Examples of localities recovered from the literature of outbreaks of sarcoptic mange in wildlife species (yellow points). Examples of species affected include wolf (Canis lupus) in North America and Europe (b), Alpine Ibex (Capra ibex) in Europe (c), Southern chamois (Rupicapra pyrenaica) (d), bare-nosed wombat (Vombatus urcinus) in Australia (e), red fox (Vulpes vulpes) in multiple continents (f) and American black bear (Ursus americanus) in North America (g) 


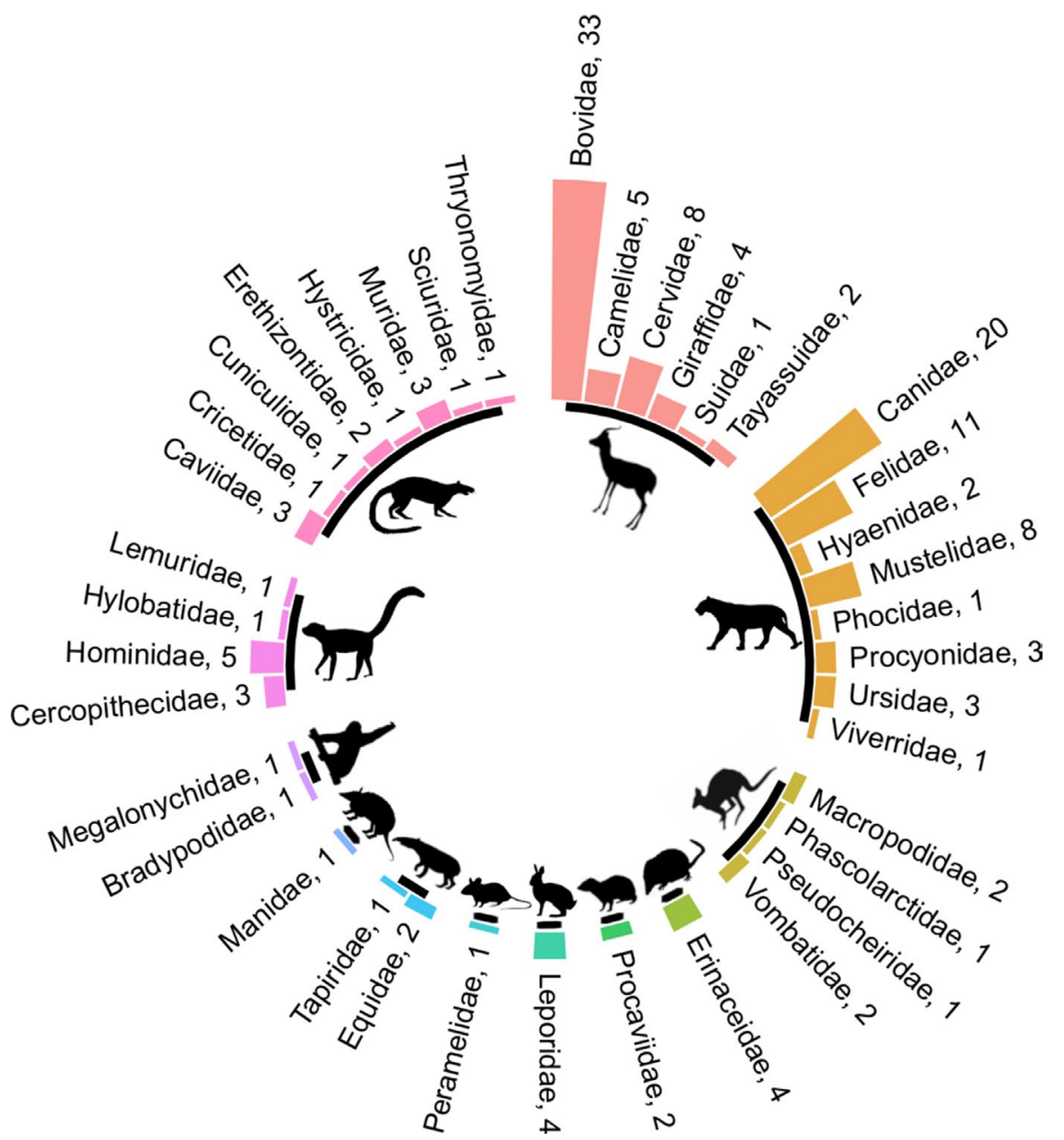

FIGURE 2 Wildlife taxa reported to be susceptible to sarcoptic mange. Hierarchical chart showing the order (internal ring) and family (external ring) of 148 mammal species known to be hosts of Sarcopes scabiei. Numbers represent the number of host species for each family. Salmon: Artiodactyla (6 families); orange: Carnivora (8 families); green-brown: Diprotodontia (4 families); dark green: Erinaceidae (1 family); bright green 1: Hyracoidea (1 family); bright green 2: Lagomorpha (1 family); greenblue: Peramelemorphia (1 family); light blue: Perissodactyla (2 families); blue: Pholidota (1 family); purple: Pilosa (2 families); bright pink: Primates (4 families, humans are excluded); pink: Rodentia (8 families)

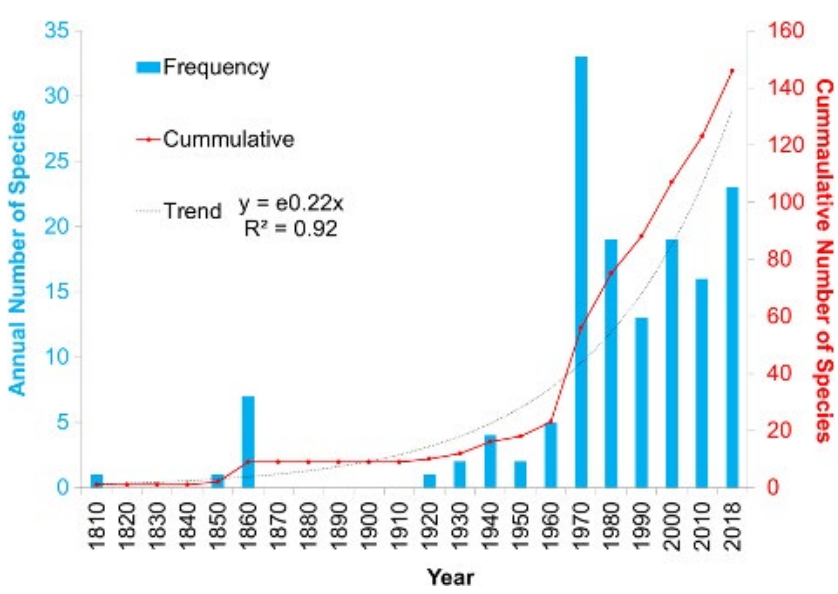

FIGURE 3 Cumulative discovery of novel hosts susceptible to Sarcoptes scabiei. Temporal distribution of discovery of novel Sarcoptes scabiei host species between 1810 and 2018. Left axis (blue): number of species reported infested with S. scabiei for the first time. Right axis (red): cumulative number of species infested with S. scabiei. Note that the trend line (grey line) suggests that more novel species are expected to be reported as susceptible to $S$. scabiei in the future. Research effort and potential bias by taxonomical group were not accounted for to be transmitted to rabbits. Similarly, S. scabiei mites from dogs (var. canis) may have low success infesting humans (Rabinowitz \& Gordon, 2004). Alternatively, host specificity could vary among different individual (e.g. sex), ecological (e.g. competition) or environmental conditions (e.g. suitable climate; Material S3).

In general, cross-species parasite transmission in a naïve host is associated with its likelihood of exposure to the parasite and its suitability to sustain an infection by allowing the parasite to overcome physical or physiological barriers. Additionally, the parasite should be able to obtain the minimal resources required to survive and reproduce (Araujo et al., 2015). Agosta and Klemens (2008) suggested a framework based on ecological fitting in which parasites colonize a naïve host in the extent at which the naïve host is ecologically and genetically similar to the original host. Alternatively, parasite colonization could be explained by the availability of new resources allowing the parasite to adapt to a new host species. These mechanisms denote the complexity of cross-species parasite transmission and, therefore, the expected limitations for its understanding and predictability.

Cross-species transmission of S. scabiei can be explored via experimental exposure to the parasite, epidemiological 
studies, and molecular tools (Martin, Fraser, et al., 2018; RenteríaSolís et al., 2014). We found that $S$. scabiei cross-species transmission has been reported for $38 \%(n=56)$ of the known host species (Figure 4, Table S1). Cross-species transmission of S. scabiei is more frequent in some host orders compared with others. For example, we found that $42 \%$ of host species in the Artiodactyla Order have reports of cross-species transmission, 28.8\% in Carnivora and $11.5 \%$ in Rodentia, mainly from natural transmissions (Table S1).

Numerous molecular markers have been used to understand S. scabiei host specificity, parasite cross-species transmission and geographic origin. For example, based on microsatellite markers Walton et al. (2004) suggested human-to-human transmission as the most important epidemiological pathway for scabies, and a minor relevance of zoonotic transmission from dogs. These studies concerning the degree of host specificity are important for the development of effective control measures. For example, recent phylogenetic analyses have identified genetic exchange among $S$. scabiei populations collected in different sympatric hosts living in geographic isolation; that is, analyses revealed specific parasite haplotypes related to spatial units among different hosts. Therefore, categorizing S. scabiei populations according to their hosts (i.e. var) could be misleading when parasite genetic structure does not support host differentiation, and instead, S. scabiei lineages may follow biogeographic rules (Alasaad, Oleaga, et al., 2011; Amer et al., 2014; Gakuya et al., 2011; Makouloutou et al., 2015; Rasero et al., 2010).

FIGURE 4 Network of cross-species transmission of Sarcoptes scabiei. Nodes represent hosts, while size nodes represent the connection degree as a proxy of number of spillover (connections) of S. scabiei among nodes. Green: wildlife species. Blue: domestic species (humans are excluded). Light blue: domestic species with free-ranging sub-species or populations. Note that research effort and potential bias by taxonomical group were not accounted for
Molecular markers have been also used to explore geographic origin of S. scabiei populations, to reconstruct transmission, and to trace evolutionary patterns. For example, based on molecular markers dogs and humans have been found to be the original source of $S$. scabiei in native wildlife in Australia, culminating into a current endemic infestation (Fraser, Holme, et al., 2018; Skerratt et al., 2002). At a coarse scale, human-mediated movements have facilitated S. scabiei expansion across geographic barriers (Makouloutou et al., 2015), with multiple cross-species transmission events to wildlife occurring during multiple periods (Peltier et al., 2017). Therefore, recurrent S. scabiei introductions by humans may explain outbreaks and sarcoptic mange endemicity in wildlife populations, creating mixedmite populations with genetic structure not entirely explained by host variants (Fraser et al., 2016).

Sarcoptes scabiei diversity detected by molecular tools is strongly dependent upon the marker used with different nuclear, ribosomal and mitochondrial genes providing different signals (Fraser et al., 2017). It is possible that optimal molecular markers are yet to be identified, or that mite adaptation to the host is instead epigenetic. A future frontier in S. scabiei research should include wholegenome sequencing, detection of a set of target sequences for more accurate lineage identification and genetic characterization to develop tools for understanding host specificity, spillover mechanisms, mite population dynamics, sources of infestation and geographical origin (Alasaad, Oleaga, et al., 2011; Fraser, Holme, et al., 2018; Peltier et al., 2017; Rasero et al., 2010; Walton et al., 1999).

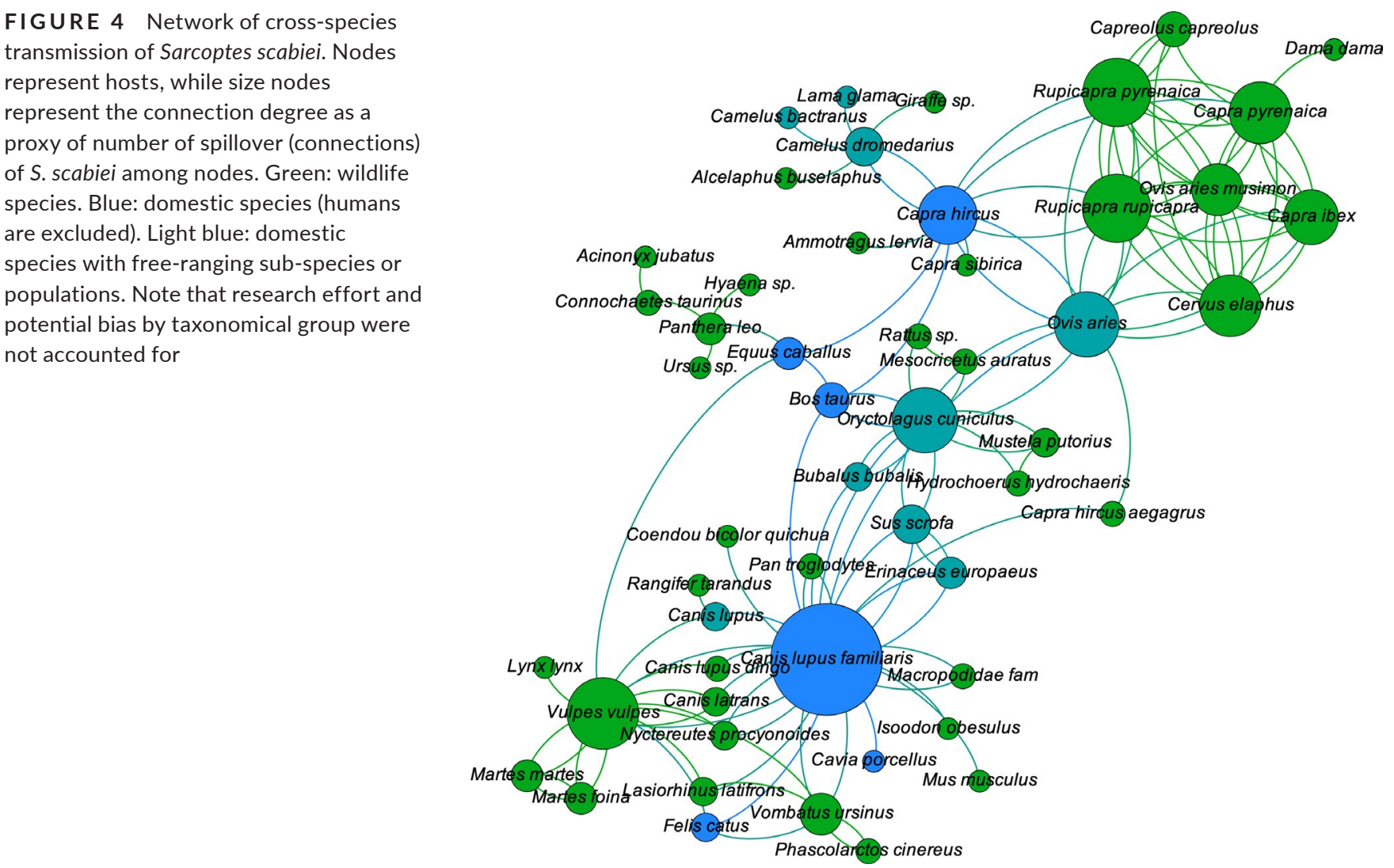


The phylogenetic structure of S. scabiei is still inconsistent. In Europe, microsatellite studies revealed that $S$. scabiei mites presented mostly a host taxon-specific structure, clustering into three groups: herbivore-derived, carnivore-derived and omnivore-derived (Alasaad, Oleaga, et al., 2011; Rasero et al., 2010). This pattern has also been described among wildlife in Asia (Matsuyama et al., 2019). Alternatively, S. scabiei genetic structure has also followed a prey-predator cluster, suggesting that this ecological interaction could facilitate contact opportunity and therefore explain S. scabiei spillover among wildlife. For example, S. scabiei populations obtained from cheetah (Acinonys jubatus) and ngu (Connochaetes taurinus) presented an isolated cluster in Africa (Gakuya et al., 2011). Stephens et al. (2019) found similar structure in a series of parasites in Europe, suggesting that predator-prey spillover may represent a general rule in disease ecology.

The structure of host specificity of both macro- and microparasites may follow patterns based on host phylogenetic distance (i.e. taxonderived), host ecology (i.e. predator-prey) and geography (i.e. spatial overlap), where the latter two are associated with contact opportunities. Nevertheless, these contact opportunities could be induced by humans. For example, many reports of cross-species transmission in wildlife are derived from unnatural encounters generated in laboratory experiments, captivity of diverse species (e.g. zoos), and artificially large distribution and high density of domestic animals. This transmission potential may not be homogenous among $S$. scabiei lineages with some studies describing that specific $S$. scabiei lineages could be more host-specific than others (Andriantsoanirina et al., 2015; Skerratt et al., 2002; Zhao et al., 2015). Therefore, S. scabiei lineages could be related to host, taxa, specific ecological interactions or a locality.

Cross-species S. scabiei transmission has a complex structure. According to our literature review, cross-species transmission patterns suggest that a network of $S$. scabiei has clusters of semiisolated groups of host species (Figure 4, Gephi Software, Bastian et al., 2009). In this network (Figure 4), the nodes represent host species, and the node size resembles connection degree as a proxy of number of $S$. scabiei transmission to other host species, differentiating wild (green) and domestic (blue) hosts, the latter including free-ranging populations of domestic hosts (light blue). Our overview revealed that domestic species are more connected (i.e. higher connectivity) and may have a key role on S. scabiei transmission pathways to wildlife hosts. The role of domestic animals in cross-species transmission to wildlife has been suggested for viruses based on molecular data (e.g. Wells et al., 2018) and epidemiological studies (Acosta-Jamett et al., 2011). Thus, domestic animals, such as dogs, would act as reservoirs of $S$. scabiei facilitating the parasite's global spread and may contribute to cross-species transmission to wildlife. From a conservation perspective, the $S$. scabiei transmission network suggests that the free-ranging behaviour of dogs and other domestic species is a threat for wild species of conservation concern (Werner \& Nunn, 2020). Because dogs are widely distributed and occur at high densities, they have been identified as 'bridge hosts' of infectious diseases among humans, other domestic animals and wildlife (Pedersen et al., 2007; Poo-Muñoz et al., 2016).
Beyond wildlife hosts, S. scabiei represents a parasite of emerging interest in the human-wildlife-domestic animal interface. Sarcoptes scabiei spillover events from wildlife have been linked to outbreaks in livestock, pets and humans (Pisano, Ryser-Degiorgis, et al., 2019; Rabinowitz \& Gordon, 2004). As with other pathogens such as West Nile virus, wildlife species may serve as 'sentinel animals' for human health (Lerner, 2019). For livestock, wildlife may become an additional source for sarcoptic mange, which may be derived in economic losses (Gortázar et al., 2007).

\section{5 | TRANSMISSION DYNAMICS}

Sarcoptes scabiei transmission is associated with biotic and abiotic factors (Table 1, Material S3), and depends on direct and indirect exposure (Arlian \& Morgan, 2017; Arlian et al., 1988). Biotic factors such as host behaviour (e.g. gregarious species) and demography (e.g. host density) facilitate direct transmission. Indeed, behaviours that facilitate contact, including allogrooming, mating and territorial fights, are linked to sarcoptic mange infestations (Pérez et al., 1997; Rossi et al., 2007) and seasonality (Table 1 and Material S3). Abiotic factors, such as environmental change, may lead to overcrowding of single or multiple host species (Carricondo-Sanchez et al., 2017; Corriale et al., 2013). In solitary species, non-social transmission mechanisms may become relevant. For example, solitary species may have predator-prey encounters (Fuchs et al., 2016; Gakuya et al., 2011), intraguild predation (Kolodziej-Sobocinska et al., 2014; Linnell et al., 1998) or carrion consumption (Alasaad, Ndeereh, et al., 2012; Andrews, 1983).

Sarcoptes scabiei transmission also occurs by indirect contact (i.e. environmental transmission). In environmental transmission, the off-host survival of $S$. scabiei is a key factor determined by environmental conditions (Arlian et al., 1984, 1989; Niedringhaus et al., 2019). At fine scale, environment transmission may be facilitated by adequate microclimate of resting areas, dens and burrows used by foxes, badgers and wombats (Kolodziej-Sobocinska et al., 2014; Kraabøl et al., 2015; Martin et al., 2019; MontecinoLatorre et al., 2019; Skerratt et al., 1998). Nevertheless, the understanding of resting areas for S. scabiei transmission is still not well understood (Beeton et al., 2019; Montecino-Latorre et al., 2019). At coarse scale, environmental transmission is suspected to depend on S. scabiei off-host survival in fomites (e.g. cattle straw beds, concrete, wood; Bornstein \& de Verdier, 2010), which explains seasonality of sarcoptic mange outbreaks (Pérez et al., 1997; Vander Haegen et al., 2013). Under this scenario, climate change is expected to impact sarcoptic mange incidence, which has been proposed for human infectious diseases (IPCC, 2007). In practice, it is difficult to determine when S. scabiei infectinfestations occur via direct or indirect transmission (Fuchs et al., 2000; Kraabøl et al., 2015). Under unsuitable environmental conditions for S. scabiei (e.g. snow), direct transmission may be the most parsimonious explanation (Kraabøl et al., 2015). 
TAB LE 1 Summary of factors associated with Sarcoptes scabiei transmission and severity

\begin{tabular}{|c|c|}
\hline Feature & Description \\
\hline $\begin{array}{l}\text { 1. Host density and } \\
\text { social structure }\end{array}$ & $\begin{array}{l}\text { In general, social species (with higher densities) are more vulnerable to sarcoptic mange outbreaks (i.e. density-dependent } \\
\text { transmission; Sugiura et al., 2018), and transmission tends to be associated with higher densities of hosts (Kido } \\
\text { et al., 2013). Nevertheless, other studies have shown no effect of host density (Samelius et al., 2016). Prey densities } \\
\text { (that indirectly may induce predator-host density) have also been suggested as influential for sarcoptic mange outbreaks } \\
\text { (Mörner, 1992) }\end{array}$ \\
\hline $\begin{array}{l}\text { 2. Age and sex- } \\
\text { related features: } \\
\text { contradictions }\end{array}$ & $\begin{array}{l}\text { Higher susceptibility in juveniles camels (Zahid et al., 2015) and lower susceptibility in juvenile capybaras (Corriale } \\
\text { et al., 2013) have been described. Meanwhile, higher susceptibility has been reported in male Iberian Ibex (López-Olvera } \\
\text { et al., 2015) and in female camels (Feyera et al., 2017). Other studies show no differences between sexes (Almberg } \\
\text { et al., 2015) }\end{array}$ \\
\hline $\begin{array}{l}\text { 3. Environmental } \\
\text { conditions }\end{array}$ & $\begin{array}{l}\text { Seasonality has been described as a relevant feature for sarcoptic mange outbreaks (Kotb \& Abdel-rady, 2015), in particular, } \\
\text { in those conditions that may favour Sarcoptes survival (Pérez et al., 1997). In fact, in seasons with unsuitable conditions for } \\
\text { mite survival, sarcoptic mange prevalence tends to be lower (Carricondo-Sanchez et al., 2017). Stressful environments for } \\
\text { the host (e.g. harsh winters) have also been associated with sarcoptic mange outbreaks (Skerratt et al., 1998) }\end{array}$ \\
\hline $\begin{array}{l}\text { 5. Host-parasite } \\
\text { interaction }\end{array}$ & $\begin{array}{l}\text { Naïve populations (with poorer immune response) may present more severe consequences when confronted to a novel } \\
\text { pathogen (Pence \& Windberg, 1994; Rossi et al., 1995). Poor immune response (with higher susceptibility, lethality) is also } \\
\text { present in debilitated animals. Some authors suggest that emerging outbreaks result from changes in virulence of the } \\
\text { S. scabiei population (Vander Haegen et al., 2018) }\end{array}$ \\
\hline
\end{tabular}

\section{6 | HOST-PARASITE INTERACTIONS AND CLINICAL SEVERITY}

At the host individual level, S. scabiei impacts are associated with host-parasite interactions (i.e. immune response), which are reflected in the clinical presentation of sarcoptic mange. Clinical signs of sarcoptic mange result from the burrowing process of $S$. scabiei into the skin and the exaggerated immune response of the host (Bhat et al., 2017; Davidson et al., 2008). Common sarcoptic mange clinical signs include intense pruritus, crusty dermatitis, erythema and papule formation (Bornstein et al., 2001; OIE, 2016). In the first stages of the infestation, S. scabiei mites are able to suppress the host immune response (Arlian \& Morgan, 2017). Later on, the skin may become hyperkeratotic, with diverse levels of hair loss, excoriation and fissuring of skin (Skerratt et al., 1999). Immune hypersensitivity causes rash and pruritus in domestic dogs (Bhat et al., 2017; Bornstein et al., 2001), but presents differently in red foxes, lynx (Lynx lynx) and coyotes (C. latrans; Little et al., 1998), where sarcoptic mange is observed with limited pruritus and alopecia (Pence \& Ueckermann, 2002). In general, the clinical presentation varies among species but after several weeks, as $S$. scabiei proliferate and its population is established, inflammatory immune responses are stimulated, and clinical signs are manifested. This immune response causes physiological and behavioural changes in the host. Signs in wildlife species are described in detail in Material S4.

Different levels of resistance to the infestation, including different severity of symptoms and immune response, have been observed among species, populations and individuals (Pence \& Windberg, 1994). For example, sarcoptic mange impacts are variable among populations of wolves (Almberg et al., 2012; KolodziejSobocinska et al., 2014) and among individuals of Iberian ibex (Capra pyrenaica) from the same population (Pérez et al., 2019). Specific individuals may have genetic predisposition to more intense sarcoptic mange, including crusted mange, referred to as Norwegian or crusted scabies in humans (Bhat et al., 2017). Crusted mange has been described in cats (Malik et al., 2006), wombats (Skerratt, 2003) and dogs (Kaltsogianni et al., 2017), but monitoring in other animal species is needed. In general, wildlife populations are considered more susceptible to develop clinical signs of sarcoptic mange compared with domestic animals due to an observed reduction in resistance to infestation, and environmental stress (e.g. harsh winters, drought; Martin et al., 1998). Risk factors for S. scabiei transmission and sarcoptic mange severity in wildlife have contradictory results, which we discuss in detail in Material S3. Briefly, some studies suggest that sex and age influence sarcoptic mange susceptibility and severity; meanwhile, others have found no relation (Corriale et al., 2013; Feyera et al., 2017; López-Olvera et al., 2015). Other studies highlight the relevance of disease pre-existence, body condition of the host and stressing environmental conditions on the development of immune response. For example, unusual mortality due to sarcoptic mange was reported in debilitated giraffes during a drought period in Kenya (Alasaad, Ndeereh, et al., 2012). Thus, climate change, beyond facilitating transmission, may also play a role increasing severity of sarcoptic mange infestations by affecting the host immunity.

Sarcoptic mange symptoms and impacts are not limited to the skin and may also generate metabolic, physiological and behavioural change (Material S4). Sarcoptes scabiei infestation triggers a chain of host metabolism changes due to the costs of immune response 
and energy loss, linked to reduced thermoregulation from alopecia and dysfunctional integument characteristics (Martin, Fraser, et al., 2018; Serrano et al., 2007; Simpson et al., 2016). This inappropriate control of body temperature may be critical in wildlife exposed to extreme weather events (Simpson et al., 2016). Infested individuals often have altered haematological and serum biochemical parameters due to anaemia, protein loss, hypoglycaemia and internal organs undergo metabolic alterations (Arlian et al., 1990; Skerratt et al., 1999). Similarly, experimental infestations reveal that juvenile individuals have slower growing rates, lower body weight, delayed ossification and smaller bones (Rehbein et al., 2003; Serrano et al., 2007). Sarcoptic mange may also lead to reduced feeding, food consumption and resting, resulting in poorer efficiency of food conversion (Fentanew et al., 2018; Suthersr, 1987). Secondary bacterial infections may also impact internal organs and systemic function (Chandler \& Fuller, 2018). Finally, sarcoptic mange may progress to a debilitating and multisystemic disease that affects fitness and may provoke death (Martin, Fraser, et al., 2018; Skerratt et al., 2004). In wildlife, reduction in fitness may significantly impact the short-term survival of a population.

Long-term studies suggest a host-parasite co-evolutionary force that decreases sarcoptic mange presentation by reducing the exaggerated immune response of hosts, even though the $S$. scabiei infestation remains (Davidson et al., 2008). In fact, sarcoptic mange outbreaks may include a large proportion of asymptomatic individuals (Davidson et al., 2008; Fuchs et al., 2016). Based on experimental evidence, some species may gain resistance to $S$. scabiei reinfestation or clinical sarcoptic mange (Arlian et al., 1984; Bhat et al., 2017; Skerratt, 2003), while others do not gain such resistance (Almberg et al., 2015). The little information regarding wildlife immune response to $S$. scabiei is that naïve hosts have exaggerated anti-inflammatory, anti-immune and anti-complement responses, generating severe sarcoptic mange (Arlian \& Morgan, 2017).

\section{7 | SARCOPTIC MANGE DETECTION: NOVEL APPROACHES}

The gold standard sarcoptic mange diagnosis is based on clinical signs and morphological identification of $S$. scabiei by microscopic observation of skin scrapings (OIE, 2016). Modern diagnostic methods include enzyme-linked immunosorbent assay (ELISA) used to detect IgG antibodies against $S$. scabiei, which can be useful in serological surveys to identify exposed individuals with asymptomatic or resolved infestations (Peltier et al., 2018; Ráez-Bravo et al., 2016; Rambossi et al., 2004). Molecular diagnostic tests have been used in both humans and animals for direct $S$. scabiei detection (Angelone-Alasaad et al., 2015; Makouloutou et al., 2015; Peltier et al., 2018; Zhao et al., 2015). Indeed, comparative diagnostics have revealed that polymerase chain reaction (PCR) assays on skin scraping are an advancement method to detect $S$. scabiei compared with traditional microscopy, clinical diagnoses and other methods (Fraser, Holme, et al., 2018). The most frequent gene used for $S$. scabiei detection is the internal transcribed spacer (ITS)-2 region in nuclear ribosomal DNA (Peltier et al., 2018). Angelone-Alasaad et al. (2015) reported universal conventional and real-time PCR diagnosis tools for $S$. scabiei detection from skin scrapings based on mitochondrial DNA.

Non-invasive techniques are particularly relevant when monitoring wildlife diseases present in free-ranging animals. In particular, infestations with $S$. scabiei may present visible lesions that enable non-invasive and observational diagnoses. Some studies have used citizen science approaches (e.g. questionnaires; Gakuya et al., 2012) and camera traps (i.e. photo trapping), based on the identification of classic external lesions resembling sarcoptic mange (Arenas et al., 2002; Brewster et al., 2017; Fraser, Carver, et al., 2018; Sugiura et al., 2018). Citizen science represents a feasible method to complement quantitative methods in which hunters, farmers, game wardens and park rangers provide epidemiological information (Gakuya et al., 2012; Montecino-Latorre et al., 2020; Pisano, Ryser-Degiorgis, et al., 2019, Pisano, Zimmermann, et al., 2019; Ryser-Degiorgis, 2013; Skelton et al., 2019). Other non-invasive methods include infrared thermal imaging (Figure 5) and detector dogs. Infrared thermal imaging is particularly innovative and may also generate data concerning the body condition and thermoregulation impacts in infested individuals (e.g. Cross et al., 2016). Finally, detector dogs have been reported as successful, using trained dogs to follow the scent of Sarcoptes-infested animals and to find carcasses, even under snow (Alasaad, Permunian, et al., 2012). Future efforts should include the development of standardized diagnostic methods for sarcoptic mange cases and outbreaks including collection of metadata (e.g. species, location, date, genetic sequences) to build a repository of the global burden of sarcoptic mange in wildlife (Alasaad, Walton, et al., 2011).

\section{8 | WILDLIFE CONSERVATION}

\subsection{General effects in wildlife}

Sarcoptic mange not only may have impacts at individual level (e.g. clinical presentations and severity) but also may have impacts at community, population and species level. The introduction of virulent pathogens and parasites to naïve host populations can result in significant population declines and localized extinctions (GonzálezAstudillo et al., 2018; Tompkins et al., 2015), scaling from isolated outbreaks that may become epizootics (Carvalho et al., 2015; Table 2). A series of studies propose sarcoptic mange as a threat to susceptible wildlife populations (e.g. Martin, Fraser, et al., 2018; Montecino-Latorre et al., 2020; Mörner, 1992; Smith et al., 2009; Tompkins et al., 2015) (but see Pence \& Ueckermann, 2002). For instance, sarcoptic mange is one of the few diseases, along with rabies, canine distemper and canine parvovirus, known to affect the population dynamics of wild canids (Gortázar et al., 1998).

There are reports of sarcoptic mange causing extirpation of entire wildlife populations (González-Astudillo et al., 2018; Pence 

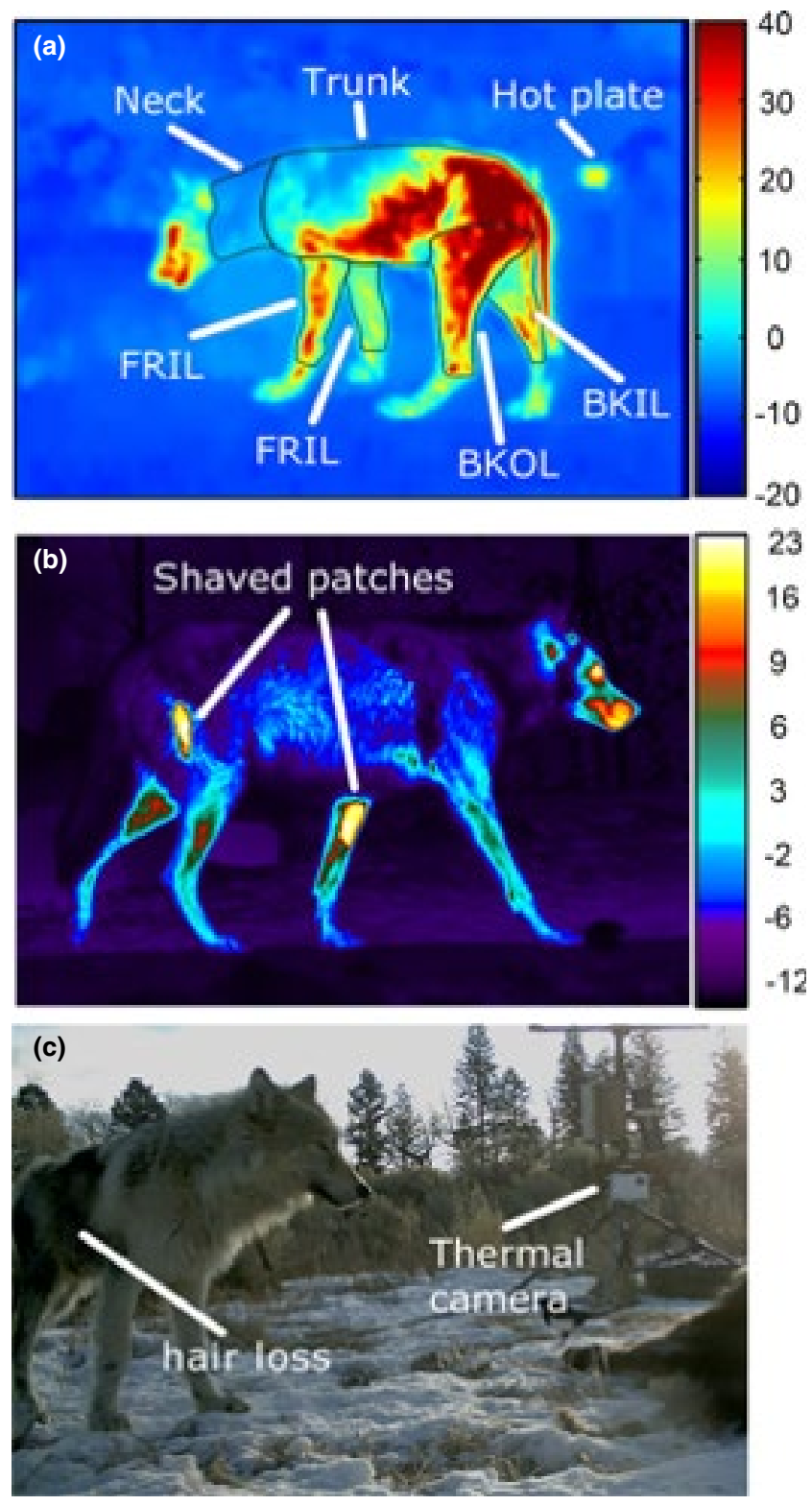

FIGURE 5 Telediagnoses of sarcoptic mange via infrared thermal imagining and photo trapping. Thermal imagery of field (a) and captive (b) wolves showing hair loss due to sarcoptic mange and shaved patches, respectively. BKOL, back outer leg; BKIL, back inner leg; FROL, front outer and inner leg;. Panels a and c are wolves infested with sarcoptic mange. Modified from Cross et al. (2016)

\& Ueckermann, 2002). For example, populations of the common wombat (Vombatus ursinus) present periodic sarcoptic mange outbreaks with drastic (>94\%) local declines (Gray, 1937; Martin, Fraser, et al., 2018). Similarly, sarcoptic mange caused $~ 80 \%$ population decline of the Northern chamois (Rupicapra r. rupicapra) in the Eastern Alps (Buzan et al., 2013), and $70 \%$ decline in coyotes populations in Northern Texas (Pence \& Windberg, 1994), with similar levels of mortality reported in red foxes and grey wolves (Lindstrom et al., 1994; Little et al., 1998; Mörner, 1992; Pence \& Windberg, 1994).

Studies of sarcoptic mange epizootics in wildlife generally focus on a single host species, neglecting the potential impacts of outbreaks at a community level (but see Kolodziej-Sobocinska et al., 2014). It is expected that infestations of naïve susceptible host populations with drastic declines (>70\%) can trigger cascading effects on the ecosystem and modify the assemblage of the community, while demographic and ecological variations in one wildlife species can indirectly affect other species. For example, extended outbreaks of sarcoptic mange in red fox, a predator, may benefit populations of roe deer (Capreolus capreolus) and black grouse (Lyrurus tetrix), among other preys (Alsaker, 2017; Lindstrom et al., 1994; Thulin et al., 2015). In addition, sarcoptic mange-induced cascading effects may increase the prevalence of other parasites and pathogens circulating in prey populations. In urban areas of North America, the mortality of wild canids due to sarcoptic mange is suspected to increase the risk of Lyme disease for humans due to the increased abundance and contact of rodents (Miller et al., 2018). On the other hand, red fox declines due to sarcoptic mange were potentially beneficial for the arctic fox (Alopex lagopus) by reducing apparent competition between the two fox species (Kraabøl et al., 2015). Thus, S. scabiei can be a keystone species that modulates wildlife species assemblages and interactions.

Sarcoptic mange effects on wildlife may be underestimated considering that available data on outbreaks in wildlife often come from anecdotal reports and grey literature. In regions of Latin America, reports of wildlife sarcoptic mange outbreaks are usually restricted to unpublished records, biodiversity non-governmental organizations, and natural resources agencies (CONAF, 2014; Grimberg Pardo, 2010). Despite its deleterious effects, sarcoptic mange is not considered to be a notifiable disease by the World Organization for Animal Health (OIE, 2019a). Sarcoptic mange is, however, included in the list of human-wildlife diseases from the World Animal Health Information System-Wildlife Interface (OIE, 2019b), acknowledged as a neglected tropical disease of humans by the World Health Organization (WHO, 2018), and considered risk by the Intergovernmental Panel of Climate Change (IPCC, 2007). Institutional and scientific reports could also be biased to wildlife species close to urban settlements (e.g. red fox, coyotes), species under intense effort for conservation and research (e.g. wombats), or species of economic importance in farming (e.g. camels) or sport hunting (e.g. cervids and mountain-dweling caprines). Similarly, our current understanding of sarcoptic mange could be biased towards species suffering high prevalence and more severe symptoms, excluding asymptomatic wildlife species that may be contributing to S. scabiei maintenance, disperse and spillover. Therefore, a more detailed understanding of the geographic and host range distribution of sarcoptic mange and variation in its virulence among species could help to reconstruct $S$. scabiei evolutionary biology and epidemic potential.

\section{2 | Threat for conservation}

Sarcoptic mange is considered to be one of the ten most threatening wildlife diseases associated with population decline for 
TABLE 2 Sarcoptic mange as a threat for wildlife: four potential scenarios and examples

\begin{tabular}{|c|c|c|c|}
\hline Species & $\begin{array}{l}\text { Conservation } \\
\text { Status }\end{array}$ & Description & Reference \\
\hline \multicolumn{4}{|c|}{ 1) Threatened species with no confirmed reports of sarcoptic mange infestation but with reports in closely related/sympatric species } \\
\hline $\begin{array}{l}\text { Northern hairy-nosed } \\
\text { wombat (L. krefftii) }\end{array}$ & CE & $\begin{array}{l}\text { No reports in this wombat species yet; however, the } \\
\text { other two close wombat species highly susceptible } \\
\text { to sarcoptic mange with periodic outbreaks }\end{array}$ & Martin, Burridge, et al. (2018)) \\
\hline \multicolumn{4}{|c|}{ 2) Threatened species with previous reports of sarcoptic mange (i.e. known to be susceptible hosts) } \\
\hline Cheetah (A. jubatus) & VU & $\begin{array}{l}\text { Sarcoptic mange being placed among the leading } \\
\text { causes of death }\end{array}$ & $\begin{array}{l}\text { Gakuya et al. (2011); Mwanzia } \\
\text { et al. (1995) }\end{array}$ \\
\hline $\begin{array}{l}\text { Mountain gorilla ( } G \text {. } \\
\text { beringei beringei) }\end{array}$ & CE & $\begin{array}{l}\text { A report of a sarcoptic mange outbreak in Uganda } \\
\text { in a free-ranging family group that provoke fatal } \\
\text { cases in juveniles. Unpredictable outcomes if new } \\
\text { outbreaks occur }\end{array}$ & Kalema-Zikusona et al. (2002) \\
\hline
\end{tabular}

3) Not necessarily a threatened species, but in which a few affected individuals could affect specific populations
Arctic fox (A. lagopus; $\quad$ LC V. lagopus according to
Sarcoptic mange outbreaks in a small local population of arctic foxes required capture/ treatment/ release
Mörner (1992) IUCN)

4) Not necessarily a threatened species, but a susceptible host with decreasing populations, external pressures and/or in which sarcoptic mange have generated strong effects

$\begin{array}{lll}\text { Hedgehog (E. europaeus) } \quad \text { LC } & \begin{array}{l}\text { A decline of an invasive population was attributed } \\ \text { to sarcoptic mange outbreaks in New Zealand } \\ \text { (introduced). Until now, this has not been the case in } \\ \text { its native range in Europe. }\end{array} \\ \begin{array}{c}\text { Bare-nosed or common } \\ \text { wombat (V. ursinus) }\end{array} & \begin{array}{l}\text { Sarcoptic mange is an endemic disease, causing } \\ \text { occasional declines on infested populations (up } \\ \text { to } 94 \%) \text {. Additional conservation pressures could } \\ \text { enhance the effect of sarcoptic mange outbreaks. }\end{array} \\ \text { Alpine ibex (C. ibex) } & \text { LC } & \begin{array}{l}\text { Sarcoptic mange outbreaks have reduced their } \\ \text { population in the eastern Alps, Europe, particularly } \\ \text { in Italy. The assemble of susceptible host herbivores } \\ \text { in the area and the increasing conservation } \\ \text { pressures could enhance the effects of those } \\ \text { outbreaks. }\end{array}\end{array}$

Kolodziej-Sobocinska et al. (2014);

Kriechbaum and Pomroy (2018)

Martin, Burridge, et al. (2018)); Tompkins et al. (2015)

Reviewed in De Danieli and Sarasa, (2015)

Note: Four scenarios in the assessment of sarcoptic mange as a threat for wildlife species, considering its susceptibility, current risk of transmission and conservation category (IUCN, 2019). IUCN categories: CE: critically endangered; EN: endangered; VU: vulnerable, NT: near threat, LC: least concern.

some species, and recognized as a new challenge in biodiversity conservation (Ciliberti et al., 2015; Cypher et al., 2017; Martin, Burridge, et al., 2018; Montecino-Latorre et al., 2020; Pence \& Ueckermann, 2002; Tompkins et al., 2015). Nevertheless, in some host species sarcoptic mange may not necessarily represent a major pressure compared with other wildlife diseases. Our literature review reveals that $27 \%$ of the current species described as hosts (40/148) are in some suboptimal conservation status according to the International Union for Conservation of Nature Classification (IUCN, 2019). Among those, two S. scabiei host species are listed as Critically Endangered (CE), 11 are Endangered (EN), 18 are Vulnerable (VU), and nine are Near Threatened (NT).
Nevertheless, only $2 \%$ of the overall mammal species under suboptimal conservation status are described as susceptible to sarcoptic mange, having large differences among orders. For instance, 14\% $(15 / 108)$ of the species under suboptimal conservation status of Carnivora are considered susceptible to sarcoptic mange, 13\% $(1 / 8)$ in order Philosa and 8\% (13/157) in Artiodactyla. Therefore, sarcoptic mange could represent an important additional pressure to be considered within carnivore species that are already of conservation concern. In addition, according to Pedersen et al. (2007), S. scabiei is one of the three arthropods identified as causing populations declines or reduced host fitness in mammals listed in the IUCN Red List as 'Threatened'. 
Most S. scabiei host species categorized as CE and EN have sarcoptic mange reports from captivity (7/13), especially in zoos and laboratories, depicting susceptibility at least under unnatural conditions. In free-ranging conditions, S. scabiei monitoring is challenging. For example, some infected Iberian lynxes (L. pardinus) do not show alopecia, limiting capacity for early S. scabiei detection (Oleaga et al., 2019). In gorillas (Gorilla berengei), a sarcoptic mange outbreak was reported in $30 \%$ of individuals of a free-ranging family group, including lethal cases in juveniles (Graczyk et al., 2001). In this outbreak, gorillas were habituated to human presence (e.g. tourists and local communities; Graczyk et al., 2001). The identification of reservoir species that may be favouring $S$. scabiei transmission may be relevant to control and prevent outbreaks, especially when spatial overlap exists with threatened species. A proper management of biosecurity in tourism and preventive strategies with local communities could have a protective impact on the endangered wildlife, which could also protect wildlife from other human-derived diseases.

There is an increased interest in the role of emerging infectious disease in wildlife, defined as diseases recently discovered, with increased occurrence, geographical extension or host range (Daszak, 2013). Baseline data on wildlife diseases are frequently unknown and are usually described only after an outbreak occurs (Lange et al., 2014). According to Pedersen et al. (2007), diseases associated with species decline tend to affect a wide range of host species, have a wide range of transmission modes and also tend to affect domestic animals. Wildlife diseases, however, may have mild presentations or have less long-term impacts. For example, densitydependent diseases may have endemic cycles, in which populations may cope and recover from outbreaks (Anderson, 1991; Rossi et al., 2007). This could be the case of sarcoptic mange outbreaks with drastic population decline in red foxes, followed by an endemic phase with progressive recovery (Pisano, Zimmermann, et al., 2019). In contrast, the disease may truly have unpredictably and threatening impacts in other wild species (Martin, Fraser, et al., 2018). Therefore, the impact of sarcoptic mange in wildlife depends on several features and their specific contexts.

To predict the potential risk of sarcoptic mange in a specific population, researchers should consider the characteristics of previous outbreaks. Nevertheless, considering the scarce understanding of factors associated with sarcoptic mange severity, the assessment of risks should consider other general scenarios. As a general frame for assessing and prioritizing the potential impact of sarcoptic mange in wild species, wildlife epidemiologists could consider four scenarios: (a) threatened species with no confirmed reports of sarcoptic mange infestation but infestations have occurred in closely related/ sympatric species; (b) threatened species with previous reports of sarcoptic mange (i.e. considered susceptible host); (c) not necessarily a threatened species but susceptible hosts, in which a few affected individuals could have serious impacts on specific populations; and (d) susceptible host species not of current conservation concern but with decreasing populations, under external pressures, or where sarcoptic mange has generated long-term effects in past infestations (see details and examples of these four scenarios in Table 2).
The active intervention to control sarcoptic mange spread among wildlife has been explored at length with contradictory results. Methods have included treatment of individuals, populations, environmental disinfection and culling (Lunelli, 2010; Martin et al., 2019; Rowe et al., 2019). The use of drugs for sarcoptic mange treatment has not been consistently successful in wildlife, and the development of vaccines for wildlife species remains in its infancy (Martin et al., 2019). Nevertheless, interventions should be based on specific assessments, which may include the goal of intervention (e.g. elimination or control), the role of other species in the transmission, the impact of outbreaks at individual, population and community levels, and the influence of environmental conditions on transmission and the severity of the infestation. As with other wildlife diseases, the same strategies for disease control are not suitable for all host species, and control may be feasible for some species or geographic contexts but infeasible for others.

\section{9 | FINAL REMARKS}

The impact of wildlife diseases is increasingly considered for biodiversity conservation. Diseases that affect humans, wildlife and domestic animals require multidisciplinary research approaches. Sarcoptic mange has a global distribution and affects a wide range of host species including humans, presenting uneven impacts. Recent studies report increased severity, novel host species and expanded geographic range of sarcoptic mange in wildlife. Thus, sarcoptic mange could be categorized as an emerging global wildlife disease with active transmission, and a novel threat for biodiversity conservation. Future research efforts should include the development of control strategy guidelines, explore a potential link of host traits with disease susceptibility, and host specificity. A global repository of S. scabiei data in wildlife is urgently needed for a more comprehensive monitoring among taxa and geographies. Additionally, the economic costs of S. scabiei in livestock and pets and the public health impacts of $S$. scabiei in endemic areas should be revisited in future research. In conclusion, evidence suggests that sarcoptic mange in wildlife could be considered an emerging panzootic.

\section{ACKNOWLEDGEMENTS}

Mariana Castaneda-Guzman provided support in figure preparation. Anila Kalonia assisted with identifying reports of $S$. scabiei among host species. This research was supported by the Australian Research Council Linkage Program (LP180101251) to Scott Carver. Luis Escobar was supported by the Global Change Center and the Center for Emerging, Zoonotic, and Arthropod-borne Pathogens at Virginia Tech. Any use of trade, firm or product names is for descriptive purposes only and does not imply endorsement by the U.S. Government.

\section{DATA AVAILABILITY STATEMENT}

Data supporting this review are available in the supplementary materials in .csv and .docx format. 


\section{ORCID}

Luis E. Escobar (iD https://orcid.org/0000-0001-5735-2750

Scott Carver iD https://orcid.org/0000-0002-3579-7588

Michael J. Yabsley iD https://orcid.org/0000-0003-2452-5015

Christian Gortázar (iD https://orcid.org/0000-0003-0012-4006

\section{REFERENCES}

Acosta-Jamett, G., Chalmers, W. S. K., Cunningham, A. A., Cleaveland, S., Handel, I. G., Bronsvoort, \& B. M. C. (2011). Urban domestic dog populations as a source of canine distemper virus for wild carnivores in the Coquimbo region of Chile. Veterinary Microbiology, 152(3), 247257. https://doi.org/10.1016/j.vetmic.2011.05.008

Agosta, S. J., \& Klemens, J. A. (2008). Ecological fitting by phenotypically flexible genotypes: Implications for species associations, community assembly and evolution. Ecology Letters, 11(11), 1123-1134. https:// doi.org/10.1111/j.1461-0248.2008.01237.x

Alasaad, S., Ndeereh, D., Rossi, L., Bornstein, S., Permunian, R., Soriguer, R. C., \& Gakuya, F. (2012). The opportunistic Sarcoptes scabiei: A new episode from giraffe in the drought-suffering Kenya. Veterinary Parasitology, 185(2-4), 359-363. https://doi.org/10.1016/j. vetpar.2011.10.039

Alasaad, S., Oleaga, Á., Casais, R., Rossi, L., Min, A. M., Soriguer, R. C., \& Gortázar, C. (2011). Temporal stability in the genetic structure of Sarcoptes scabiei under the host-taxon law: Empirical evidences from wildlife-derived Sarcoptes mite in Asturias, Spain. Parasites \& Vectors, 4, 151-158. https://doi.org/10.1186/1756-3305-4-151

Alasaad, S., Permunian, R., Gakuya, F., Mutinda, M., Soriguer, R. C., \& Rossi, L. (2012). Sarcoptic-mange detector dogs used to identify infected animals during outbreaks in wildlife. BMC Veterinary Research, 8, 110-117. https://doi.org/10.1186/1746-6148-8-110

Alasaad, S., Walton, S., Rossi, L., Bornstein, S., Abu-Madi, M., Soriguer, R. C., Fitzgerald, S., Zhu, X. Q., Zimmermann, W., Ugbomoiko, U. S., Pei, K. J. C., \& Heukelbach, J. (2011). Sarcoptes-World Molecular Network (Sarcoptes-WMN): Integrating research on scabies. International Journal of Infectious Diseases, 15(5), 294-297. https:// doi.org/10.1016/j.ijid.2011.01.012

Almberg, E. S., Cross, P. C., Dobson, A. P., Smith, D. W., \& Hudson, P. J. (2012). Parasite invasion following host reintroduction: A case study of Yellowstone's wolves. Philosophical Transactions of the Royal Society B: Biological Sciences, 367(1604), 2840-2851. https://doi. org/10.1098/rstb.2011.0369

Almberg, E. S., Cross, P. C., Dobson, A. P., Smith, D. W., Metz, M. C., Stahler, D. R., \& Hudson, P. J. (2015). Social living mitigates the costs of a chronic illness in a cooperative carnivore. Ecology Letters, 18(7), 660-667. https://doi.org/10.1111/ele.12444

Alsaker, L. H. (2017). Effects of forestry, predators and weather on capercaillie (Tetrao urogallus) and black grouse (Lyrurus tetrix) in South-East Norway. Norwegian University of Life Sciences.

Amer, S., El Wahab, T. A., El Naby Metwaly, A., Ye, J., Roellig, D., Feng, Y., \& Xiao, L. (2014). Preliminary molecular characterizations of Sarcoptes scabiei (Acari: Sarcoptidae) from farm animals in Egypt. PLoS One, 9(4), 1-6. https://doi.org/10.1371/journ al.pone.0094705

Anderson, R. M. (1991). Populations and infectious diseases: Ecology or epidemiology? Journal of Animal Ecology, 60(1), 1-50. https://doi. org $/ 10.2307 / 5443$

Andrews, J. R. R. H. (1983). The origin and evolution of host associations of Sarcoptes scabiei and the subfamily Sarcoptinae Murray. Acarologia, 24(1), 85-94.

Andriantsoanirina, V., Ariey, F., Izri, A., Bernigaud, C., Fang, F., Charrel, R., Foulet, F., Botterel, F., Guillot, J., Chosidow, O., \& Durand, R. (2015). Sarcoptes scabiei mites in humans are distributed into three genetically distinct clades. Clinical Microbiology and Infection, 21(12), 1107-1114. https://doi.org/10.1016/j.cmi.2015.08.002

Angelone-Alasaad, S., Min, A. M., Pasquetti, M., Alagaili, A. N., Amelio, S. D., Berrilli, F., Obanda, V., Gebely, M. A., Soriguer, R. C., \& Rossi, L. (2015). Universal conventional and real-time PCR diagnosis tools for Sarcoptes scabiei. Parasites \& Vectors, 8, 587. https://doi.org/10.1186/ s13071-015-1204-8

Araujo, S. B. L., Braga, M. P., Brooks, D. R., Agosta, S. J., Hoberg, E. P., Von Hartenthal, F. W., \& Boeger, W. A. (2015). Understanding hostswitching by ecological fitting. PLoS One, 10(10), 1-17. https://doi. org/10.1371/journal.pone.0139225

Arenas, A. J., Gómez, F., Salas, R., Carrasco, P., Borge, C., Maldonado, A., O'Brien, D., \& Martínez-Moreno, F. (2002). An evaluation of the application of infrared thermal imaging to the tele-diagnosis of sarcoptic mange in the Spanish ibex (Capra pyrenaica). Veterinary Parasitology, 109(1-2), 111-117. https://doi.org/10.1016/s0304 $-4017(02) 00248-0$

Arlian, L. G., Bruner, R. H., Stuhlman, R. A., Ahmed, M., \& VyszenskiMoher, D. L. (1990). Histopathology in hosts parasitized by Sarcoptes scabiei. Journal of Parasitology, 76, 889-894. https://doi. org $/ 10.2307 / 3282810$

Arlian, L. G., \& Morgan, M. S. (2017). A review of Sarcoptes scabiei: Past, present and future. Parasites \& Vectors, 10(1), 297. https://doi. org/10.1186/s13071-017-2234-1

Arlian, L. G., Morgan, M. S., \& Arends, J. J. (1996). Immunologic crossreactivity among various strains of Sarcoptes scabiei. Journal of Parasitology, 82(1), 66-72. https://doi.org/10.2307/3284117

Arlian, L. G., Morgan, M. S., \& Rider, S. D. (2016). Sarcoptes scabiei: Genomics to proteomics to biology. Parasites \& Vectors, 9, 380. https://doi.org/10.1186/s13071-016-1663-6

Arlian, L. G., Runyan, R. A., Achar, S., \& Estes, S. A. (1984). Survival and infestivity of Sarcoptes scabiei var. canis and var. hominis. Journal of the American Academy of Dermatology, 11(2), 210-215. https://doi. org/10.1016/S0190-9622(84)70151-4

Arlian, L. G., Runyan, R. A., \& Estes, S. A. (1984). Cross infestivity of Sarcoptes scabiei. Journal of the American Academy of Dermatology, 10(6), 979-986. https://doi.org/10.1016/S0190-9622(84)80318-7

Arlian, L. G., Vyszenski-Moher, D., \& Cordova, D. (1988). Host specificity of S. scabiei var. canis (Acari: Sarcoptidae) and the role of host odor. Journal of Medical Entomology, 25(1), 52-56. https://doi.org/10.1093/ jmedent/25.1.52

Arlian, L. G., Vyszensky-Moher, D. L., \& Pole, M. J. (1989). Survival of adults and developmental stages of Sarcoptes scabiei var. canis when off the host. Experimental \& Applied Acarology, 6, 181-187. https:// doi.org/10.1007/BF01193978

Astorga, F., Carver, S., Almberg, E. S., Sousa, G. R., Wingfield, K., Niedringhaus, K. D., Wick, P. V., Rossi, L., Xie, Y., Cross, P., Angelone, S., Gortázar, C., \& Escobar, L. E. (2018). International meeting on sarcoptic mange in wildlife, June 2018, Blacksburg, Virginia, USA. Parasites \& Vectors, 11, 449. https://doi.org/10.1186/s1307 1-018-3015-1

Astorga, F., Escobar, L. E., Poo-Muñoz, D. A., Escobar-Dodero, J., RojasHucks, S., Alvarado-Rybak, M., Duclos, M., Romero-Alvarez, D., Molina-Burgos, B. E., Peñafiel-Ricaurte, A., Toro, F., Peña-Gómez, F. T., \& Peterson, A. T. (2018). Distributional ecology of Andes hantavirus: A macroecological approach. International Journal of Health Geographics, 17(1), 1-12. https://doi.org/10.1186/s12942-018-0142-z

Bastian, M., Heymann, S., \& Jacomy, M. (2009). Gephi: An open source software for exploring and manipulating networks. I. International AAAI Conference on Weblogs and Social Media, Article 0.9.2

Beeton, N. J. N., Carver, S., \& Forbes, L. K. (2019). A model for the treatment of environmentally transmitted sarcoptic mange in bare-nosed wombats (Vombatus ursinus). Journal of Theoretical Biology, 462, 466474. https://doi.org/10.1016/j.jtbi.2018.11.033 
Bhat, S. A., Mounsey, K. E., Liu, X., \& Walton, S. F. (2017). Host immune responses to the itch mite, Sarcoptes scabiei, in humans. Parasites \& Vectors, 10, 385-397. https://doi.org/10.1186/s13071-017-2320-4

Bornstein, S., \& de Verdier, K. (2010). Some important ectoparasites of alpaca (Vicugna pacos) and Ilama (Lama glama). Journal of Camelid Science, 3, 49-61.

Bornstein, S., Mörner, T., \& Samuel, W. M. (2001). Sarcoptes scabiei and sarcoptic mange. In W. M. Samuel, M. J. Pybus, \& A. A. Kocan (Eds.), Parasitic diseases of wild mammals (2nd Ed, pp. 107-119). lowa State University Press.

Bourguignon, H. (1851). Recherches sur la contagion de la gale des animaux a l'homme et sur les moeurs de I Acarus de la gale. Gazelle Medical Paris, 6(39), 661-662.

Brewster, K., Henke, S. E., Hilton, C., \& Ortega, S. A. Jr (2017). Use of remote cameras to monitor the potential prevalence of sarcoptic mange in Southern Texas. Journal of Wildlife Diseases, 53(2), 1-5. https://doi.org/10.7589/2016-08-180

Buzan, E., Bryja, J., Zemanová, B., Krystufek, B., \& Krys, B. (2013). Population genetics of chamois in the contact zone between the Alps and the Dinaric Mountains: Uncovering the role of habitat fragmentation and past management. Conservation Genetics, 14, 401-412. https://doi.org/10.1007/s10592-013-0469-8

Carricondo-Sanchez, D., Odden, M., Linnell, J., \& Odden, J. (2017). The range of the mange: Spatiotemporal patterns of sarcoptic mange in red foxes (Vulpes vulpes) as revealed by camera trapping. PLoS One, 12(4), e0176200. https://doi.org/10.1371/journal.pone.0176200

Carvalho, J., Granados, J. E., López-olvera, J. R., Cano-manuel, F. J., Pérez, J. M., Fandos, P., Soriguer, R. C., Velarde, R., Fonseca, C., Ráez, A., Espinosa, J., Pettorelli, N., \& Serrano, E. (2015). Sarcoptic mange breaks up bottom-up regulation of body condition in a large herbivore population. Parasites and Vectors, 8, 572. https://doi. org/10.1186/s13071-015-1188-4

Chandler, D. J., \& Fuller, C. (2018). A review of scabies: An infestation more than skin deep. Dermatology, 235(2), 79-90. https://doi. org/10.1159/000495290

Ciliberti, A., Gavier-Widén, D., Yon, L., Hutchings, M. R., \& Artois, M. (2015). Prioritisation of wildlife pathogens to be targeted in European surveillance programmes: Expert-based risk analysis focus on ruminants. Preventive Veterinary Medicine, 118(4), 271-284. https://doi. org/10.1016/j.prevetmed.2014.11.021

CONAF (2014). Catastro nacional descriptivo sobre enfermedades de la fauna vertebrada presente en las áreas silvestres protegidas del estado y su definición de recomendaciones generales para su manejo (C. Cunazza, \& M. Diaz (Eds.)). Corporación Nacional Forestal (CONAF).

Corriale, M. J., Orozco, M. M., Jiménez Perez, I., Conservation, T., \& Trust, L. (2013). Parámetros poblacionales y estado sanitario de Carpinchos (Hydrochoerus hydrochaeris) en lagunas artificiales de los Esteros del Iberá. Mastozoología Neotropical, 20(1), 31-45.

Cross, P. C., Almberg, E. S., Haase, C. G., Hudson, P. J., Maloney, S. K., Metz, M. C., Munn, A. J., Nugent, P., Putzeys, O., Stahler, D. R., Stewart, A. C., \& Smith, D. W. (2016). Energetic costs of mange in wolves estimated from infrared thermography. Ecology, 97(8), 19381948. https://doi.org/10.1890/15-1346.1

Currier, R. W., Walton, S. F., \& Currie, B. J. (2012). Scabies in animals and humans: History, evolutionary perspectives, and modern clinical management. Annals of the New York Academy of Sciences, 1230, 5060. https://doi.org/10.1111/j.1749-6632.2011.06364.x

Cypher, B. L., Rudd, J. L., Westall, T. L., Woods, L. W., Stephenson, N., Foley, J. E., Richardson, D., \& Clifford, D. L. (2017). Sarcoptic mange in endangered kit foxes (Vulpes macrotis mutica): Case histories, diagnoses, and implications for conservation. Journal of Wildlife Diseases, 53(1), 46-53. https://doi.org/10.7589/2016-05-098

Daszak, P. (2013). Emerging infectious diseases of wildlife - Threats to biodiversity and human. Science, 443(2000), https://doi.org/10.1126/ science. 287.5452 .443
Davidson, R. K., Bornstein, S., \& Handeland, K. (2008). Long-term study of Sarcoptes scabiei infection in Norwegian red foxes (Vulpes vulpes) indicating host/parasite adaptation. Veterinary Parasitology, 156, 277-283. https://doi.org/10.1016/j.vetpar.2008.05.019

De Danieli, C., \& Sarasa, M. (2015). Population estimates, density - dependence and the risk of disease outbreaks in the Alpine ibex Capra ibex. Animal Biodiversity and Conservation, 38(1), 101-119. https://doi. org/10.32800/abc.2015.38.0101

Devenish-Nelson, E. S., Richards, S. A., Harris, S., Soulsbury, C., \& Stephens, P. A. (2014). Demonstrating frequency-dependent transmission of sarcoptic mange in red foxes. Biology Letters, 10(10), 20140524. https://doi.org/10.1098/rsbl.2014.0524

Fain, A. (1968). Etude de la varibilite de Sarcoptes scabiei avec une revision des Sarcoptidae. Acta Zoologica Et Pathologica, 47, 3-196.

Fazal, S., Cheema, K. J., Manzoor, F., \& Maqbool, A. (2016). Experimental transmission of canine scabies to domestic rabbits, Oryctolagus Cuniculus. Pakistan Journal of Zoology, 48(5), 1449-1452.

Fentanew, A., Derso, S., \& Melaku, S. (2018). A review on epidemiology of mange mites in small ruminants. Acta Parasitologica Globalis, 6(3), 182-192. https://doi.org/10.5829/idosi.apg.2015.6.3.95234

Fernández-Morán, J., Gómez, S., Ballesteros, F., Quirós, P., Benito, J., Feliu, C., \& Nieto, J. (1997). Epizootiology of sarcoptic mange in a population of cantabrian chamois (Rupicapra pyrenaica parva) in Northwestern Spain. Veterinary Parasitology, 73(1-2), 163-171. https://doi.org/10.1016/s0304-4017(97)00061-7

Feyera, T., Megersa, M., Maalin, K., Gizaw, Y., \& Asmare, T. (2017). Major ectoparasites infesting Camelus dromedarius in three districts of Somali Regional State. Eastern Ethiopia. World Applied Sciences Journal, 35(1), 96-103. https://doi.org/10.5829/idosi.wasj.2017.96.103

Fraser, T. A., Carver, S., Martin, A. M., Mounsey, K., Polkinghorne, A., \& Jelocnik, M. (2018). A Sarcoptes scabiei specific isothermal amplification assay for detection of this important ectoparasite of wombats and other animals. PeerJ, 6, e5291. https://doi.org/10.7717/ peerj.5291

Fraser, T. A., Charleston, M., Martin, A., Polkinghorne, A., \& Carver, S. (2016). The emergence of sarcoptic mange in Australian wildlife: An unresolved debate. Parasites \& Vectors, 9(1), 1-11. https://doi. org/10.1186/s13071-016-1578-2

Fraser, T. A., Holme, R., Martin, A., Whiteley, P., Montarello, M., Raw, C., Carver, S., \& Polkinghorne, A. (2018). Expanded molecular typing of Sarcoptes scabiei provides further evidence of disease spillover events in the epidemiology of sarcoptic mange in Australian marsupials. Journal of Wildlife Diseases, 55(1), 231-237. https://doi. org/10.7589/2018-04-101

Fraser, T. A., Shao, R., Fountain-Jones, N. M., Charleston, M., Martin, A., Whiteley, P., Holme, R., Carver, S., \& Polkinghorne, A. (2017). Mitochondrial genome sequencing reveals potential origins of the scabies mite Sarcoptes scabiei infesting two iconic Australian marsupials. BMC Evolutionary Biology, 17, 233-242. https://doi.org/10.1186/ s12862-017-1086-9

Fuchs, B., Zimmermann, B., Wabakken, P., Bornstein, S., Månsson, J., Evans, A. L., Liberg, O., Sand, H., Kindberg, J., Ågren, E. O., \& Arnemo, J. M. (2016). Sarcoptic mange in the Scandinavian wolf Canis lupus population. BMC Veterinary Research, 12, 156-168. https://doi. org/10.1186/s12917-016-0780-y

Fuchs, K., Deutz, A., \& Gressmann, G. (2000). Detection of space - time clusters and epidemiological examinations of scabies in chamois. Veterinary Parasitology, 92, 63-73. https://doi.org/10.1016/S0304 $-4017(00) 00269-7$

Fürstenberg, A. (1861). Die Krätzmilben der Menschen und Thiere. Engelman. https://doi.org/10.5962/bhl.title.50460

Gakuya, F., Ombui, J., Heukelbach, J., Maingi, N., Muchemi, G., Ogara, W., Mijele, D., \& Alasaad, S. (2012). Knowledge of mange among Masai pastoralists in Kenya. PLoS One, 7(8), e43342. https://doi. org/10.1371/journal.pone.0043342 
Gakuya, F., Rossi, L., Ombui, J., Maingi, N., Muchemi, G., Ogara, W., Soriguer, R. C., \& Alasaad, S. (2011). The curse of the prey: Sarcoptes mite molecular analysis reveals potential preyto-predator parasitic infestation in wild animals from Masai Mara, Kenya. Parasites \& Vectors, 4, 193-200. https://doi. org/10.1186/1756-3305-4-193

González-Astudillo, V., León-Alvarado, O. D., Ossa-López, P. A., RiveraPáez, F. A., \& Ramírez-Chaves, H. E. (2018). Sarcoptic mange in wild quichua porcupines (Coendou quichua Thomas, 1899) in Colombia. International Journal for Parasitology: Parasites and Wildlife, 7(1), 9598. https://doi.org/10.1016/j.ijppaw.2018.02.002

Gortázar, C., Ferroglio, E., Höfle, U., Frölich, K., \& Vicente, J. (2007). Diseases shared between wildlife and livestock: A European perspective. European Journal of Wildlife Research, 53(4), 241-256. https://doi.org/10.1007/s10344-007-0098-y

Gortázar, C., Villafuerte, R., Blanco, J. C., Fernandez-De-Luco, D., \& Fernández-De-Luco, D. (1998). Enzootic sarcoptic mange in red foxes in Spain. Zeitschrift Für Jagdwissenschaft, 44, 251-256. https://doi. org/10.1007/BF02242030

Graczyk, T. K., Mudakikwa, A., Cranfield, M., \& Eilenberg, U. (2001). Hyperkeratotic mange caused by Sarcoptes scabiei (Acariformes: Sarcoptidae) in juvenile human-habituated mountain gorillas (Gorilla gorilla beringei). Parasitology Research, 87, 1024-1028. https://doi. org/10.1007/s004360100489

Gray, D. F. (1937). Sarcoptic mange affecting wild fauna in New South Wales. Australian Veterinary Journal, 13, 154-155. https://doi. org/10.1111/j.1751-0813.1937.tb04110.x

Grimberg Pardo, M. P. (2010). Plan Nacional de Conservación del Guanaco Lama guanicoe, Muller, 1776 en Chile 2010-2015

IPCC (2007). Climate change 2007: Synthesis report. Contribution of Working Groups I, II and III to the Fourth Assessment Report of the Intergovernmental Panel on Climate Change. Core Writing Team.

ITIS. (2020). Integrated Taxonomic Information System. https://www.ITIS.gov

IUCN (2019). The IUCN Red List of Threatened Species. International Union for Conservation Fo Nature https://www.iucnredlist.org

Kalema-Zikusona, G., Kock, R., \& Macfie, E. (2002). Scabies in freeranging mountain gorillas (Gorilla beringei beringei) in Bwindi Impenetrable National Park, Uganda. Veterinary Record, 150(5), 1215. https://doi.org/10.1136/vr.150.1.12

Kaltsogianni, F., Farmaki, R., \& Koutinas, A. F. (2017). Norwegian or crusted sarcoptic mange in two leishmanial dogs. Journal of the American Animal Hospital Association, 53(6), 326-330. https://doi. org/10.5326/JAAHA-MS-6445

Kido, N., Itabashi, M., Takahashi, M., \& Futami, M. (2013). Epidemiology of sarcoptic mange in free-ranging raccoon dogs (Nyctereutes procyonoides) in Yokohama. Japan. Veterinary Parasitology, 191(1-2), 102107. https://doi.org/10.1016/j.vetpar.2012.07.026

Kolodziej-Sobocinska, M., Zalewski, A., \& Kowalczyk, R. (2014). Sarcoptic mange vulnerability in carnivores of the Białowieza Primeval Forest, Poland: Underlying determinant factors. Ecological Research, 29, 237244. https://doi.org/10.1007/s11284-013-1118-x

Kotb, S., \& Abdel-rady, A. (2015). Sarcoptic mange of camel in upper Egypt: Prevalence, risk assessment, and control measures. Journal of Advance Veterinary and Animal Research, 2(12), 410-417. https://doi. org/10.5455/javar.2015.b109

Kraabøl, M., Gundersen, V., Fangel, K., \& Olstad, K. (2015). The taxonomy, life cycle and pathology of Sarcoptes scabiei and Notoedres cati (Acarina, Sarcoptidae): A review in a fennoscandian wildlife perspective. Fauna Norvegica, 35(21), 21-33. https://doi.org/10.5324/fn.v35i0.1652

Kriechbaum, C., Pomroy, W., \& Gedye, K. (2018). Sarcoptes scabiei on hedgehogs in New Zealand. Parasitology Research, 117(3), 697-703. https://doi.org/10.1007/s00436-017-5739-9

Kumar, M. R., Selvaraj, P., \& Venkatesan, M. (2018). Atypical Sarcoptes scabiei infection in an adult Labrador retriever. Journal of Entomology and Zoology Studies, 6(3), 92-94.
Lange, M., Siemen, H., Blome, S., \& Thulke, H. H. (2014). Analysis of spatiotemporal patterns of African swine fever cases in Russian wild boar does not reveal an endemic situation. Preventive Veterinary Medicine, 117(2), 317-325. https://doi.org/10.1016/j.prevetmed.2014.08.012

León-Vizcaíno, L., Ruíz de Ybañez, M., Cubero, M., Ortíz, J., Espinosa, J., Pérez, L., Simón, M., \& Alonso, F. (1999). Sarcoptic mange in Spanish ibex from Spain. Journal of Wildlife Diseases, 35(4), 647-659. https:// doi.org/10.7589/0090-3558-35.4.647

Lerner, H. (2019). A critical analysis of definitions of health as balance in a One Health perspective. Medicine, Health Care and Philosophy, 22(3), 453-461. https://doi.org/10.1007/s11019-018-09884-1

Lindstrom, E. R., Andren, H., Angelstam, P., Cederlind, G., Hornfeldt, B., Jaderberg, L., Lemnell, P., Martinsson, B., Skold, K., \& Swenson, J. (1994). Disease reveals the predator: Sarcoptic mange, red fox predation, and prey populations. Ecology, 75(4), 1042-1049. https://doi. org/10.2307/1939428

Lindström, E. R., \& Mörner, T. (1985). The spreading of sarcoptic mange among Swedish red foxes (Vulpes vulpes) in relation to fox population dynamics. Revue D'ecologie, 40, 211-216.

Linnell, J., Odden, J., Pedersen, V., \& Andersen, R. (1998). Records of intra-guild predation by Eurasian Lynx, Lynx lynx. The Canadian FieldNaturalist, 112(4), 707-708.

Little, S. E., Davidson, W. R., Rakich, P. M., Nixon, T. L., Bounous, D. I., \& Nettles, V. F. (1998). Responses of red foxes to first and second infection with Sarcoptes scabiei. Journal of Wildlife Disease, 34(3), 600611. https://doi.org/10.7589/0090-3558-34.3.600

López-Olvera, J. R., Serrano, E., Armenteros, A., Pérez, J. M., Fandos, P., Carvalho, J., Velarde, R., Cano-Manuel, F. J., Ráez, A., Espinosa, J., Soriguer, R. C., \& Granados, J. E. (2015). Sex-biased severity of sarcoptic mange at the same biological cost in a sexually dimorphic ungulate. Parasites \& Vectors, 8(583), 10-15. https://doi.org/10.1186/s13071-015-1186-6

Lunelli, A. (2010). An SEl model for sarcoptic mange among chamois. Journal of Biological Dynamics, 4(2), 140-157. https://doi. org/10.1080/17513750902883283

Makouloutou, P., Suzuki, K., Yokoyama, M., Takeuchi, M., Yanagida, T., \& Sato, H. (2015). Involvement of two genetic lineages of Sarcoptes scabiei mites in a local mange epizootic of wild mammals in Japan. Journal of Wildlife Diseases, 51(1), 69-78. https://doi. org/10.7589/2014-04-094

Malik, R., Stewart, K. M., Sousa, C. A., Krockenberger, M. B., Pope, S., Ihrke, P., Beatty, J., Barrs, V. R. D., \& Walton, S. (2006). Crusted scabies (sarcoptic mange) in four cats due to Sarcoptes scabiei infestation. Journal of Feline Medicine and Surgery, 8(5), 327-339. https://doi. org/10.1016/j.jfms.2006.05.005

Martin, A., Burridge, C. P., Ingram, J., Fraser, T., \& Carver, S. (2018). Invasive pathogen drives host population collapse: Effects of a travelling wave of sarcoptic mange on bare-nosed wombats. Journal of Applied Ecology, 55(1), 331-341. https://doi.org/10.1111/1365-2664.12968

Martin, A., Fraser, T., Lesku, J., Simpson, K., Roberts, G., Garvey, J., Polkinghorne, A., Burridge, C., \& Carver, S. (2018). The cascading pathogenic consequences of Sarcoptes scabiei infection that manifest in host disease. Royal Society Open Science, 5(4), 180018. https:// doi.org/10.1098/rsos.180018

Martin, A. M., Richards, S. A., Fraser, T. A., Polkinghorne, A., Burridge, C. P., \& Carver, S. (2019). Population-scale treatment informs solutions for control of environmentally transmitted wildlife disease. Journal of Applied Ecology, 56, 1-13. https://doi. org/10.1111/1365-2664.13467

Martin, R. W., Handasyde, K. A., \& Skerratt, L. F. (1998). Current distribution of sarcoptic mange in wombats. Australian Veterinary Journal, 76(6), 411-414. https://doi.org/10.1111/j.1751-0813.1998.tb123 91.x

Matsuyama, R., Yabusaki, T., Senjyu, N., Okano, T., Baba, M., TsujiMatsukane, T., Yokoyama, M., Kido, N., Kadosaka, T., Kato, T., Suzuki, M., \& Asano, M. (2019). Possible transmission of Sarcoptes scabiei 
between herbivorous Japanese serows and omnivorous Caniformia in Japan: Acryptic transmission and persistence? Parasites \& Vectors, 12(1), 389-398. https://doi.org/10.1186/s13071-019-3630-5

Miller, L., Adamski, R., \& Collins, D. (2018). A review of the impact that can occur with a loss of a vibrant urban canid population to sarcoptic mange. In M. Cunningham, S. Gibbs, L. Shender, T. Waltzek, \& S. Wisely (Eds.), 67th Annual International Conference Wildlife Disease Association (p. 264). Wildlife Disease Association.

Montecino-Latorre, D., Cypher, B. L., Rudd, J. L., Clifford, D. L., Mazet, J. A. K., \& Foley, J. E. (2019). Assessing the role of dens in the spread, establishment and persistence of sarcoptic mange in an endangered canid. Epidemics, 27, 28-40. https://doi.org/10.1016/j.epidem.2019.01.001

Montecino-Latorre, D., Napolitano, C., Briseño, C., \& Uhart, M. (2020). Sarcoptic mange: An emergin threat to Chilean mammals? Perspectives in Ecology and Conservation, 18(1), 267-276. https://doi. org/10.1016/j.pecon.2020.09.007

Mörner, T. (1992). Sarcoptic mange in Swedish wildlife. Revue Scientifique Et Technique (International Office of Epizootics), 11(4), 1115-1121.

Mwanzia, J. M., Kock, R., Wambua, J. M., Kock, N., \& Jarret, O. (1995). An outbreak of sarcoptic mange in the free-living cheetah (Acinonyx jubatus) in the Mara region of Kenya. Proceeding of American Association of Zoo Veterinarians and American Association of Wildlife Veterinarians Joint Conference, 139(12), 105-112. https://doi.org/10.1017/S0031 182012000935

Niedringhaus, K. D., Brown, J. D., Ternent, M. A., Cleveland, C. A., \& Yabsley, M. J. (2019). A serosurvey of multiple pathogens in American Black Bears (Ursus americanus) in Pennsylvania, USA indicates a lack of association with sarcoptic mange. Veterinary Sciences, 6(4), 75. https://doi.org/10.3390/vetsci6040075

Niedringhaus, K. D., Brown, J., Ternent, M., Peltier, S., \& Yabsley, M. (2019). Effects of temperature on the survival of Sarcoptes scabiei of black bear (Ursus americanus) origin. Parasitology Research, 118(10), 2767-2772. https://doi.org/10.1007/s00436-019-06387-7

OIE. (2016). Mange. In OIE Manual of diagnostic tests and vaccines for terrestrial animals (6th ed., pp. 1255-1266). World Organisation for Animal Health.

OIE (2019a). OIE-Listed diseases, infections and infestations in force in 2019. Animal Health in the World. http://www.oie.int/es/sanidad-animalen-el-mundo/oie-listed-diseases-2019/

OIE. (2019b). The OIE Worldwide Monitoring System for Wild Animal Diseases. WAHIS-Wild Interface.

Oleaga, Á., García, A., Balseiro, A., Casais, R., Mata, E., \& Crespo, E. (2019). First description of sarcoptic mange in the endangered Iberian lynx (Lynx pardinus): Clinical and epidemiological features. European Journal of Wildlife Research, 65(3), 40-52. https://doi.org/10.1007/ s10344-019-1283-5

Pedersen, A. B., Jones, K. E., Nunn, C. L., \& Altizer, S. (2007). Infectious diseases and extinction risk in wild mammals. Conservation Biology, 21(5), 1269-1279. https://doi.org/10.1111/j.1523-1739.2007.00776.x

Peltier, S. K., Brown, J. D., Ternent, M. A., Fenton, H., Niedringhaus, K. D., \& Yabsley, M. J. (2018). Assays for detection and identification of the causative agent of mange in free-ranging black bears (Ursus americanus). Journal of Wildlife Diseases, 54(3), 471-479. https://doi. org/10.7589/2017-06-148

Peltier, S. K., Brown, J. D., Ternent, M., Niedringhaus, K. D., Schuler, K., Bunting, E. M., Kirchgessner, M., \& Yabsley, M. J. (2017). Genetic characterization of Sarcoptes scabiei from black bears (Ursus americanus) and other hosts in the Eastern United States. Journal of Parasitology, 103(5), 593-597. https://doi.org/10.1645/17-26

Pence, D. B., \& Ueckermann, E. (2002). Sarcoptic mange in wildlife. Revue Scientifique Et Technique International Office of Epizootics, 21(2), 385398. https://doi.org/10.20506/rst.21.2.1335

Pence, D. B., \& Windberg, L. A. (1994). Impact of a sarcoptic mange epizootic on a coyote population. Journal of Wildlife Management, 58(4), 624-633. https://doi.org/10.2307/3809675
Pérez, J. M., Molina, L., Ureña-Gutiérrez, B., Espinosa, J., López-Montoya, A. J., Boos, M., Granados, J. E., Cano-Manuel, F. J., \& Azorit, C. (2019). Individual stress responses to Sarcoptes scabiei infestation in Iberian ibex, Capra pyrenaica. General and Comparative Endocrinology, 281, 16. https://doi.org/10.1016/j.ygcen.2019.05.007

Pérez, J. M., Ruiz-Martinez, I., Granados, J. E., Soriguer, R. C., \& Fandos, P. (1997). The dynamics of sarcoptic mange in the ibex population of Sierra Nevada in Spain- influence of climatic factors. Journal of Wildlife Research, 2(1), 86-89.

Pisano, S.R.R., Ryser-Degiorgis, M.P., Rossi, L., Peano, A., Keckeis, K., \& Roosje, P. (2019). Sarcoptic mange of fox origin in multiple farm animals and scabies in humans, Switzerland, 2018. Emerging Infectious Diseases, 25(6), 1235-1238. https://doi.org/10.3201/eid2506.181891

Pisano, S. R. R., Zimmerman, R., Rossi, L., Capt, S., Akdesir, E., Bürki, R., Kunz, F., Origgi, F. C., \& Ryser-Degiorgis, M. P. (2019). Spatiotemporal spread of sarcoptic mange in the red fox (Vulpes vulpes) in Switzerland over more than 60 years: Lessons learnt from comparative analysis of multiple surveillance tools. Parasites Vectors, 12, 521-537. https:// doi.org/10.1186/s13071-019-3762-7

Poo-Muñoz, D. A., Elizondo-Patrone, C., Escobar, L. E., Astorga, F., Bermudez, S. E., Martinez-Valdevenito, C., Abarca, K., \& Medina-Vogel, G. (2016). Fleas and ticks in carnivores from a domestic - wildlife interface: Implications for public health and wildlife. Journal of Medical Entomology, 53(6), 1433-1443. https://doi.org/10.1093/jme/tjw124

Rabinowitz, P. M., \& Gordon, Z. (2004). Outfoxing a rash: Clinical example of human-wildlife interaction. EcoHealth, 1(4), 404-407. https:// doi.org/10.1007/s10393-004-0137-z

Ráez-Bravo, A., Granados, J. E., Serrano, E., Dellamaria, D., Casais, R., Rossi, L., Puigdemont, A., Cano-Manuel, F. J., Fandos, P., Pérez, J. M., Espinosa, J., Soriguer, R. C., Citterio, C., \& López-Olvera, J. R. (2016). Evaluation of three enzyme-linked immunosorbent assays for sarcoptic mange diagnosis and assessment in the Iberian ibex, Capra pyrenaica. Parasites \& Vectors, 9(1), 1-8. https://doi.org/10.1186/s13071-016-1843-4

Rambozzi, L., Mezano, A., Lavin, S., \& Rossi, L. (2004). Biotin-avidin amplified ELISA for detection of antibodies to Sarcoptes scabiei in chamois (Rupicapra spp.). Veterinary Research, 35(6), 701-708. https://doi. org/10.1051/vetres

Rasero, R., Rossi, L., Soglia, D., Maione, S., Sacchi, P., Rambozzi, L., Sartore, S., Soriguer, R. C., Spalenza, V., \& Alasaad, S. (2010). Host taxon-derived Sarcoptes mite in European wild animals revealed by microsatellite markers. Biological Conservation, 143(5), 1269-1277. https://doi.org/10.1016/j.biocon.2010.03.001

Rehbein, S., Visser, M., Winter, R., Trommer, B., Matthes, A. E., Maciel, A. E., \& Marley, S. E. (2003). Productivity effects of bovine mange and control with ivermectin. Veterinary Parasitology, 114(4), 267-284. https://doi.org/10.1016/s0304-4017(03)00140-7

Rentería-Solís, Z., Min, A., Alasaad, S., Müller, K., Michler, F.-U., Schmäschke, R., Wittstatt, U., Rossi, L., \& Wibbelt, G. (2014). Genetic epidemiology and pathology of raccoon-derived Sarcoptes mites from urban areas of Germany. Medical and Veterinary Entomology, 28(1), 98-103. https://doi.org/10.1111/mve.12079

Rossi, L., Fraquelli, C., Vesco, U., Permunian, R., Sommavilla, G. M., Carmignola, G., Da Pozzo, R., \& Meneguz, P. G. (2007). Descriptive epidemiology of a scabies epidemic in chamois in the Dolomite Alps, Italy. European Journal of Wildlife Research, 53(2), 131-141. https:// doi.org/10.1007/s10344-006-0067-x

Rossi, L., Meneguz, P., De Martin, P., \& Rodolfi, M. (1995). The epizootiology of sarcoptic mange in chamois, Rupicapra rupicapra, from the Italian Eastern Alps. Parassitologia, 37(2-3), 233-240.

Rowe, M., Whiteley, P., \& Carver, S. (2019). The treatment of sarcoptic mange in wildlife: A systematic review. Parasites \& Vectors, 12, 99112. https://doi.org/10.1186/s13071-019-3340-z

Ryser-Degiorgis, M. P. (2013). Wildlife health investigations: Needs, challenges and recommendations. BMC Veterinary Research, 9(1), 1. https://doi.org/10.1186/1746-6148-9-223 
Samelius, G., Carricondo-Sanchez, D., Samelius, G., Odden, M., \& Willebrand, T. (2016). Spatial and temporal variation in the distribution and abundance of red foxes in the Tundra and Taiga of Northern Sweden. European Journal of Wildlife Research, 62(2), 211-218. https://doi.org/10.1007/s10344-016-0995-z

Serrano, E., Granados, J., \& Pérez, J. (2007). Sarcoptic mange and metapodial development in growing male Iberian ibex (Capra pyrenaica). Veterinarian Parasitology, 144(3-4), 375-379. https://doi. org/10.1016/j.vetpar.2006.10.010

Simpson, K., Johnson, C. N., \& Carver, S. (2016). Sarcoptes scabiei: The mange mite with mighty effects on the common wombat (Vombatus ursinus). PLoS One, 11(3), e0149749. https://doi.org/10.1371/journ al.pone.0149749

Skelton, C. J., Cook, A. S., West, P., Spencer, R. J., \& Old, J. M. (2019). Building an army of wombat warriors: Developing and sustaining a citizen science project. Australian Mammalogy, 41(2), 186-195. https://doi.org/10.1071/AM18018

Skerratt, L. F. (2003). Clinical response of captive common wombats (Vombatus ursinus) infected with Sarcoptes scabiei. Journal of Wildlife Diseases, 39(1), 179-192. https://doi. org/10.7589/0090-3558-39.1.179

Skerratt, L. F., Campbell, N. J. H., Murrell, A., Walton, S., Kemp, D., \& Barker, S. C. (2002). The mitochondrial $12 S$ gene is a suitable marker of populations of Sarcoptes scabiei from wombats, dogs and humans in Australia. Parasitology Research, 88(4), 376-379. https://doi. org/10.1007/s00436-001-0556-5

Skerratt, L. F., Martin, R., \& Handasyde, K. (1998). Sarcoptic mange in wombats. Australian Veterinary Journal, 76(6), 408-410. https://doi. org/10.1111/j.1751-0813.1998.tb12389.x

Skerratt, L. F., Middleton, D., \& Beveridge, I. (1999). Distribution of life cycle stages of Sarcoptes scabiei var wombati and effects of severe mange on common wombats in Victoria. Journal of Wildlife Diseases, 35(4), 633-646. https://doi.org/10.7589/0090-3558-35.4.633

Skerratt, L. F., Skerratt, J., Martin, R., \& Handasyde, K. (2004). The effects of sarcoptic mange on the behaviour of wild common wombats (Vombatus ursinus). Australian Journal of Zoology, 52, 331-339. https:// doi.org/10.1071/ZO02062

Smith, H. J. (1986). Transmission of Sarcoptes scabiei in swine by fomites. The Canadian Veterinary Journal, 27(6), 252-254.

Smith, K. F., Acevedo-Whitehouse, K., \& Pedersen, A. B. (2009). The role of infectious diseases in biological conservation. Animal Conservation, 12(1), 1-12. https://doi.org/10.1111/j.1469-1795.2008.00228.x

Soulsbury, C. D., Iossa, G., Baker, P. J., Cole, N., Funk, S. M., \& Harris, S. (2007). The impact of sarcoptic mange Sarcoptes scabiei on the British fox Vulpes vulpes population. Mammal Review, 37(4), 278-296. https://doi.org/10.1111/j.1365-2907.2007.00101.x

Stephens, P. R., Altizer, S., Ezenwa, V. O., Gittleman, J. L., Moan, E., Han, B., Huang, S., \& Pappalardo, P. (2019). Parasite sharing in wild ungulates and their predators: Effects of phylogeny, range overlap, and trophic links. Journal of Animal Ecology, 88, 1017-1028. https://doi. org/10.1111/1365-2656.12987

Sugiura, N., Doi, K., Kato, T., Morita, T., \& Hayama, S. (2018). Epizootic of sarcoptic mange in raccoon dogs (Nyctereutes procyonoides) in relation to population density. Journal of Veterinary Medical Science, 80(3), 544-548. https://doi.org/10.1292/jvms.17-0092

Suthersr, R. W. (1987). Ectoparasites and herbivore nutrition. In J. B. Hacker, \& J. H. Ternouth (Eds.), The nutrition of herbivores (pp. 191209). Academic Press.

Thulin, C. G., Malmsten, J., \& Ericsson, G. (2015). Opportunities and challenges with growing wildlife populations and zoonotic diseases in Sweden. European Journal of Wildlife Research, 61(5), 649-656. https://doi.org/10.1007/s10344-015-0945-1
Tompkins, D. M., Carver, S., Jones, M. E., Krkos, M., \& Skerratt, L. F. (2015). Emerging infectious diseases of wildlife: A critical perspective. Trends in Parasitology, 31(4), 149-159. https://doi.org/10.1016/j. pt.2015.01.007

Vander Haegen, W. M., Orth, G. R., Johnston, A. N., \& Linders, M. J. (2018). Endemic diseases affect population dynamics of tree squirrels in contrasting landscapes. Journal of Wildlife Management, 82(2), 328-343. https://doi.org/10.1002/jwmg.21383

Vander Haegen, W. M., Orth, G., \& Linders, M. L. (2013). Survival and causes of mortality in a northern population of western gray squirrels. Journal of Wildlife Management, 77(6), 1249-1257. https://doi. org/10.1002/jwmg.567

Walton, S. F., Choy, J. L., Bonson, A., Valle, A., McBroom, J., Taplin, D., Arlian, L., Mathews, J. D., Currie, B., \& Kemp, D. (1999). Genetically distinct dog-derived and human-derived Sarcoptes scabiei in scabies-endemic communities in northern Australia. The American Journal of Tropical Medicine and Hygiene, 61(4), 542-547. https://doi. org/10.4269/ajtmh.1999.61.542

Walton, S. F., Dougalla, A., Pizzutto, S., Holtd, D., Tapline, D., Arlian, L., Morgan, M., Currie, B., \& Kemp, D. (2004). Genetic epidemiology of Sarcoptes scabiei (Acari: Sarcoptidae) in Northern Australia. International Journal for Parasitology, 34(2004), 839-849. https://doi. org/10.1016/j.ijpara.2004.04.002

Walz, G. (1809). Natur und Behandlung der Schaaf-Raude (J. Steinkopf (ed.)).

Wells, K., Morand, S., Wardeh, M., \& Baylis, M. (2018). Distinct spread of DNA and RNA viruses among mammals amid prominent role of domestic species. Global Ecology and Biogeography, 29(3), 470-481. https://doi.org/10.1111/geb.13045

Werner, C. S., \& Nunn, C. L. (2020). Effect of urban habitat use on parasitism in mammals: A meta-analysis. Proceedings Royal Society B, 287(1927), 20200397. https://doi.org/10.1098/rspb.2020.0397

WHO (2018). Scabies. World Health Organization. https://www.who.int/ es/news-room/fact-sheets/detail/scabies

Woods, R., Reiss, A., Cox-witton, K., Grillo, T., \& Peters, A. (2019). The Importance of Wildlife Disease Monitoring as Part of Global Surveillance for Zoonotic Diseases : The Role of Australia. Tropical Medicine and Infectious Disease, 4, 29. https://doi.org/10.3390/tropi calmed4010029

Zahid, M. I., Maqbool, A., Anjum, S., Ashraf, K., Khan, M. S., \& Ahmad, N. (2015). Prevalence of sarcoptic mange in camels in Punjab, Pakistan. The Journal of Animal \& Plant Sciences, 25(5), 1259-1263.

Zhao, Y. E., Cao, Z. G., Cheng, J., Hu, L., Ma, J. X., Yang, Y. J., Wang, X. P., Zeng, J. H., \& Wang, T. P. (2015). Population identification of Sarcoptes hominis and Sarcoptes canis in China using DNA sequences. Parasitology Research, 114(3), 1001-1010. https://doi.org/10.1007/ s00436-014-4266-1

\section{SUPPORTING INFORMATION}

Additional supporting information may be found online in the Supporting Information section.

How to cite this article: Escobar LE, Carver S, Cross PC, et al. Sarcoptic mange: An emerging panzootic in wildlife.

Transbound Emerg Dis. 2021;00:1-16. https://doi. org/10.1111/tbed.14082 